\title{
Peran Ekspektasi Kinerja, Ekspektasi Usaha, Pengaruh Sosial, dan Kondisi yang Mendukung terhadap Perilaku Pengguna Itqan Mobile yang Dimediasi oleh Niat Perilaku Menggunakannya
}

\author{
Chairia \\ Citra Sukmadilaga \\ Indri Yuliafitri \\ Akuntansi, Universitas Padjadjaran, Indonesia \\ Korespondensi penulis: chairia18001@mail.unpad.ac.id
}

\begin{abstract}
Baitul Maal wat Tamwil (BMT) is a sharia cooperative that is able to reach up to economic actors of Small and Medium Enterprises (SMEs). Itqan BMT members in Bandung who use Itqan Mobile are far less than the number of members who do not use them. The purpose of this study was to examine the Unified Theory of Acceptance and Use of Technology (UTAUT) on users of users and not users of Itqan Mobile on Itqan BMTs in Bandung. UTAUT is a theory that is widely adopted in studies of user acceptance of a technology. The method used in this research is regression analysis followed by path analysis. Regression analysis was carried out in two stages. The result of regression I, research is that effort expectations show a positive and significant role on the behavioral intentions of members using Itqan Mobile, while performance expectancy, social influence, and facilitating conditions do not contribute to the behavioral intentions Itqan Mobile. The results of regression II, research indicate that performance expectations and effort expectations have not role in the behavior intentions Itqan Mobile. Furthermore, the results of the study also prove that performance expectations, effort expectations, social influences, and facilitating conditions show an indirect effect on the behavior of Itqan Mobile users which is mediated by behavioral intentions of using it.
\end{abstract}

Keywords: Baitul Maal wat Tamwil (BMT); Financial technology (fintech); Mobile banking; Syar'i cooperative; UTAUT.

Abstrak. Baitul Maal wat Tamwil (BMT) adalah koperasi syariah yang mampu men-
jangkau hingga ke pelaku ekonomi Usaha Mikro, Kecil, dan Menengah (UMKM). Ang-
gota BMT Itqan di Kota Bandung yang menggunakan Itqan Mobile jauh lebih sedikit
dibandingkan jumlah anggota yang tidak menggunakannya. Tujuan penelitian adalah
untuk menguji The Unified Theory of Acceptance and Use of Technology (UTAUT) pada
anggota pengguna dan bukan pengguna Itqan Mobile pada BMT Itqan di Kota
Bandung. UTAUT adalah teori yang banyak diadopsi pada penelitian-penelitian tentang 
penerimaan pengguna terhadap suatu teknologi. Metode yang digunakan dalam penelitian ini adalah analisis regresi yang dilanjutkan dengan analisis jalur (path analysis). Analisis regresi dilakukan dengan dua tahapan. Hasil penelitian regresi I adalah ekspektasi usaha menunjukkan peran positif dan signifikan terhadap niat perilaku anggota menggunakan Itqan Mobile, sedangkan ekspektasi kinerja, pengaruh sosial, dan kondisi yang mendukung tidak berperan terhadap niat perilaku anggota menggunakan Itqan Mobile. Hasil penelitian regresi II menunjukkan bahwa ekspektasi kinerja dan ekspektasi usaha tidak berperan terhadap perilaku anggota menggunakan Itqan Mobile. Selanjutnya, hasil penelitian juga membuktikan bahwa ekspektasi kinerja, ekspektasi usaha, pengaruh sosial, dan kondisi yang mendukung menunjukkan pengaruh secara tidak langsung terhadap perilaku pengguna Itqan Mobile yang dimediasi oleh niat perilaku untuk menggunakannya.

Kata kunci: Baitul Maal wat Tamwil (BMT); Financial technology (fintech); Koperasi syariah; Mobile banking; UTAUT.

Article Info:

Received: March 4, $2020 \quad$ Accepted: May 26, $2020 \quad$ Available online: July 15, 2020

DOI: http://dx.doi.org/10.30588/jmp.v10i1.655

\section{LATAR BELAKANG}

Zaman revolusi industri 4.0 sekarang ini ditandai dengan perkembangan teknologi yang mendominasi hampir seluruh aspek kehidupan manusia (Auliani, 2018). Inovasi berbasis teknologi baru telah lahir yang semakin baik, terutama di bidang keuangan yang biasa disebut financial technology (fintech). Pertumbuhan fintech yang meningkat dari tahun sebelumnya ini akan menjadi pertimbangan perusahaan-perusahaan agar menggunakan fintech untuk mempermudah konsumennya. Salah satu solusi yang diberikan fintech adalah konsumen tidak perlu lagi datang ke outlet untuk melakukan pembayaran transaksi atau pun tagihan.

Bank Indonesia (BI) menilai bahwa fintech berperan penting dalam mendorong pengembangan ekonomi dan keuangan syariah (Uly, 2018). Indonesia telah mulai memanfaatkan teknologi dalam industri berbasis syariah, salah satunya adalah penggunaan aplikasi fintech dalam pengumpulan dan penyaluran zakat, infaq, shadaqah, dan wakaf (Uly, 2018). Dalam industri keuangan syariah, pemanfaatan fintech syariah mampu meningkatkan jangkauan pasar keuangan syariah domestik, sehingga layanan tersebut mampu meningkatkan inklusi keuangan syariah (Uly, 2018).

Gambar 1 memperlihatkan bahwa jumlah fintech konvensional jauh lebih banyak dibandingkan dengan jumlah fintech berbasis syariah. Data tersebut bersumber dari Otoritas Jasa Keuangan (2019) per tanggal 30 Oktober 2019 yang menunjukkan bahwa 144 fintech konvensional dan 13 fintech syariah telah terdaftar di Otoritas Jasa Keuangan (OJK). Komite Strategis dan Pusat Riset OJK menyampaikan bahwa peluang untuk mengembangkan financial technology (fintech) berbasis syariah masih terbuka lebar dan semakin berkembang seiring gaya hidup halal masyarakat Indonesia (Suharsih, 2019). Gaya hidup halal adalah pola perilaku masyarakat dalam berbagai aktivitas atau kegiatan mereka berdasarkan kehalalannya (Hasan, 2017). 
Perbedaan antara fintech syariah dan fintech konvensional terletak pada dasardasar yang dianut. Fintech syariah menggunakan syariah Islam sebagai dasar operasinya, sedangkan fintech konvensional menggunakan Peraturan OJK nomor 13/POJK.02/ 2018 tentang Inovasi Keuangan Digital di Sektor Jasa Keuangan. Aturan OJK tersebut merupakan ketentuan yang memayungi pengawasan dan pengaturan industri fintech yang dikeluarkan oleh OJK (Purnomo, 2018). Selain itu, ketentuan fintech syariah mengacu pada regulasi OJK nomor 77 tahun 2016 tentang layanan pinjam meminjam uang berbasis teknologi informasi dan tidak boleh bertentangan dengan fatwa Dewan Syariah Nasional Majelis Ulama Indonesia (MUI). Saat ini, banyak pihak yang telah merintis fintech syariah, tetapi belum banyak dari mereka yang terdaftar di OJK (Suharsih, 2019).

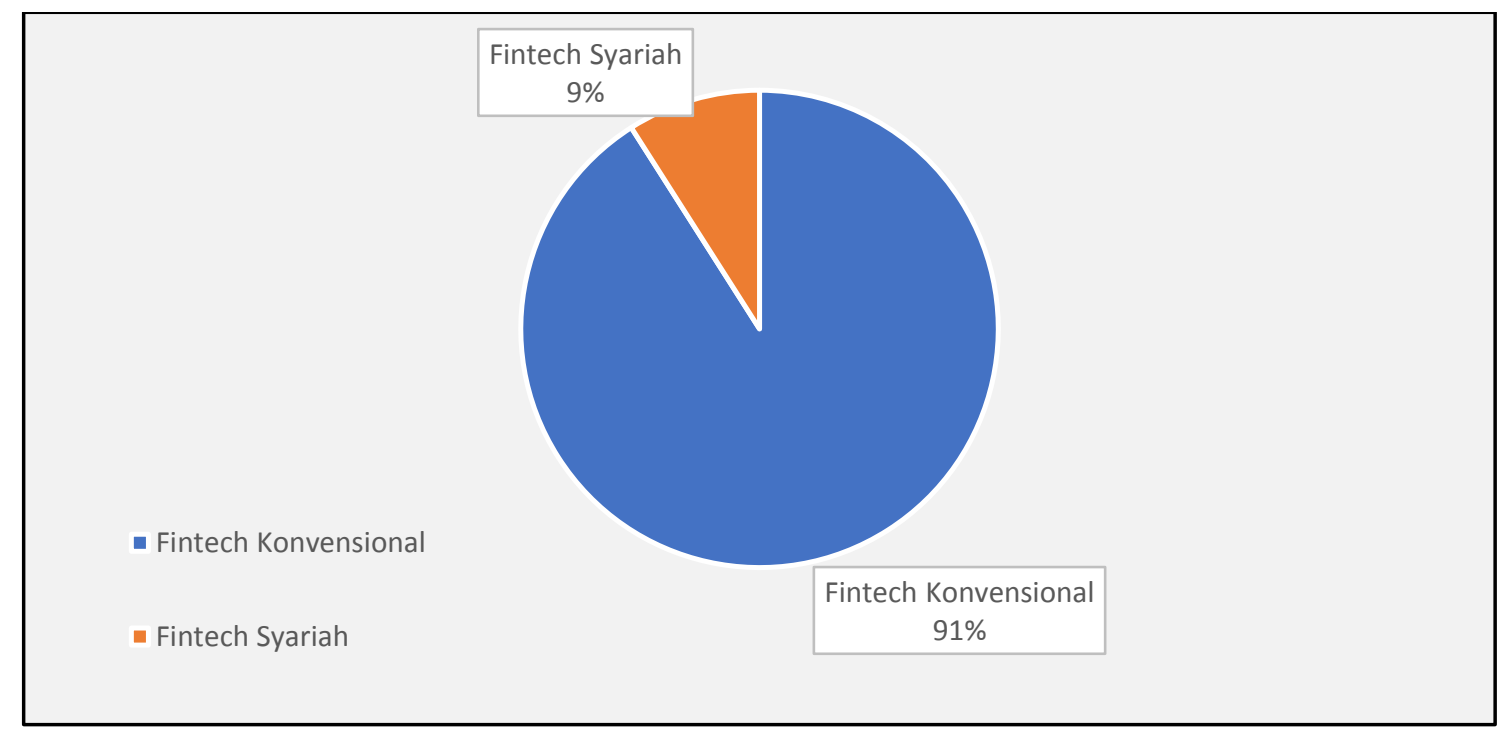

Sumber: Otoritas Jasa Keuangan (2019).

\section{Gambar 1. Jumlah Fintech yang Terdaftar di OJK}

Sekarang ini, tidak hanya perbankan konvensional yang memilik layanan berbasis fintech yang didisain untuk memudahkan mereka melayani konsumen. Namun, Baitul Maal wat Tamwil (BMT) atau koperasi syariah juga mulai memanfaatkan kecanggihan teknologi digital dalam layanannya. Untuk pertama kalinya, BMT diperkenalkan pada awal tahun 2000an (Salama, 2018). Sampai saat ini, pertumbuhan BMT terus mengalami peningkatan hingga mencapai titik yang luar biasa (Salama, 2018). Ada dua lembaga yang bertugas mengawasi dan membina BMT, yaitu Kementerian Koperasi dan UMKM dan OJK. Namun, hanya beberapa BMT saja yang memilih untuk berada di bawah pengawasan OJK (Salama, 2018). Posisi hukum BMT berada di wilayah koperasi (Akbar, 2013). Namun, BMT harus memilih jenis layanan koperasinya antara koperasi jasa ataukah koperasi simpan pinjam, karena kedua jenis koperasi tersebut diawasi oleh lembaga yang berbeda berdasarkan Undang-Undang nomor 17 tahun 2012 tentang koperasi. Jika BMT memilih jenis koperasi simpan pinjam, maka BMT tersebut akan diawasi oleh Kementerian Koperasi dan UMKM, sedangkan jika BMT memilih koperasi jasa, maka ia akan diawasi oleh OJK (Akbar, 2013). 
Berdasarkan Gambar 2, pertumbuhan BMT yang diawasi oleh OJK setiap tahun semakin meningkat, meskipun tidak dalam jumlah yang besar. Keberadaan BMT dibutuhkan untuk menjangkau pelaku ekonomi UMKM. Hasil penelitian terdahu-lu menunjukkan bahwa pembentukan BMT mayoritas didirikan oleh sekelompok masyarakat atau $62,72 \%$ yang terdiri atas organisasi massa, pesantren, masjid, dan komunitas profesional di tiga provinsi meliputi Jawa Barat, Jawa Tengah, dan Jawa Timur (Sakti, 2013). Hal ini membuktikan bahwa ada kepedulian kelompok masyarakat yang cukup besar terhadap pemberdayaan UMKM melalui pengembangan BMT. Namun, ada juga beberapa BMT berdiri atas inisiasi bank syariah. Dalam hal ini, permasalahan BMT terkait terbatasnya pendanaan dalam memenuhi pembiayaan yang dibutuhkan anggotanya dipastikan akan mendapatkan bantuan (Sakti, 2013).

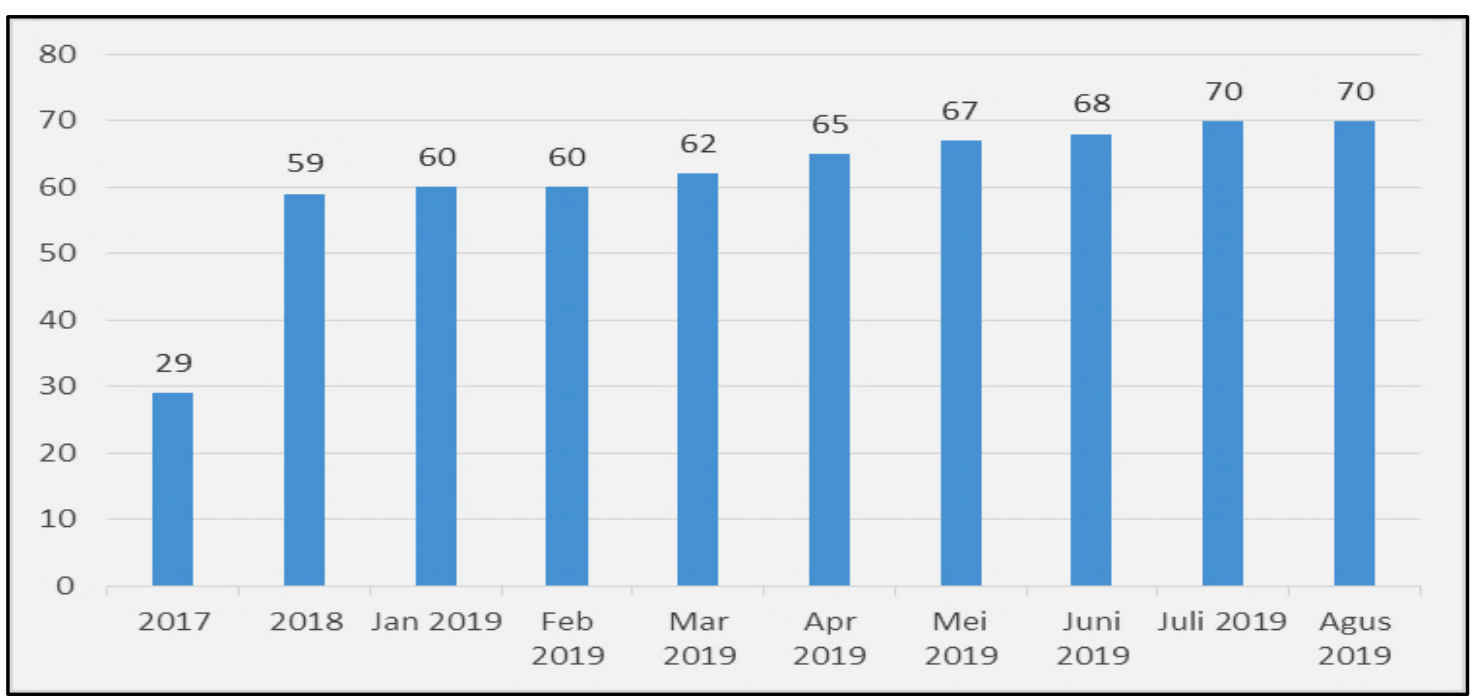

Sumber: Otoritas Jasa Keuangan (2019).

\section{Gambar 2. Jumlah BMT yang Diawasi OJK}

Selanjutnya, Gambar 3 memperlihatkan bahwa BMT sudah tersebar di banyak provinsi di Indonesia. Dengan banyaknya jumlah BMT di Indonesia, BMT diharapkan mampu menjadi lembaga penyedia keuangan yang memberikan kemudahan dalam mengakses fasilitas apa pun, seperti persyaratan peminjaman oleh pelaku UMKM. Lokasi BMT biasanya berada di wilayah perdesaan bukan di perkotaan, sehingga BMT mampu memberdayakan sektor-sektor usaha masyarakat yang berskala mikro dan kecil. Beberapa BMT telah memiliki mobile banking sendiri yang dirancang untuk memudahkan layanan mereka kepada masyarakat (Hartoyo, 2019). Sampai saat ini, penggunaan teknologi yang dirancang oleh BMT bertujuan untuk mengikuti perkembangan teknologi perbankan, seperti penggunaan kartu Anjungan Tunai Mandiri (ATM) dan rekening tabungan yang terintegrasi. Namun, karena BMT adalah lembaga keuangan dalam skala mikro dan kecil, beberapa BMT belum mampu membangun sistem teknologi informasi keuangannya. Jika BMT ingin membangun sistem teknologi finansialnya, maka BMT harus bekerja sama dengan bank-bank syariah karena mereka telah memiliki kemampuan teknologi yang lebih memadai (Salama, 2018). BMT dapat menggunakan teknologi informasi dan sistem internet sebagai infrastruktur yang mendorong kinerjanya. 
Untuk mengkaji penerimaan penggunaan teknologi fintech pada BMT, penelitian ini untuk melihat seberapa jauh keefektifan penerapan model Unified Theory of Acceptance and Use of Technology (UTAUT) dalam pemanfaatan Itqan Mobile. Variabelvariabel yang mempengaruhi penerimaan dan perilaku pengguna teknologi dalam teori tersebut adalah persepsi orang-orang terhadap ekspektasi kinerja, ekspektasi usaha, pengaruh sosial, dan kondisi yang mendukung (Venkatesh, Davis, Morris, \& Davis, 2003). Dengan demikian, penelitian ini bertujuan untuk menguji peran ekspektasi kinerja, ekspektasi usaha, pengaruh sosial, dan kondisi yang mendukung, baik secara parsial maupun simultan terhadap perilaku pengguna melalui variabel mediasi niat perilaku menggunakan Itqan Mobile. Hasil pengujian tersebut diharapkan menjadi masukan untuk BMT Itqan pada khususnya agar lebih memahami secara mendalam peran dan fungsi Itqan Mobile bagi seluruh anggota BMT Itqan. Secara umum, hasil penelitian ini akan memberikan wawasan baru tentang penerapan model UTAUT pada aplikasi fintech dalam industri BMT di Indonesia.

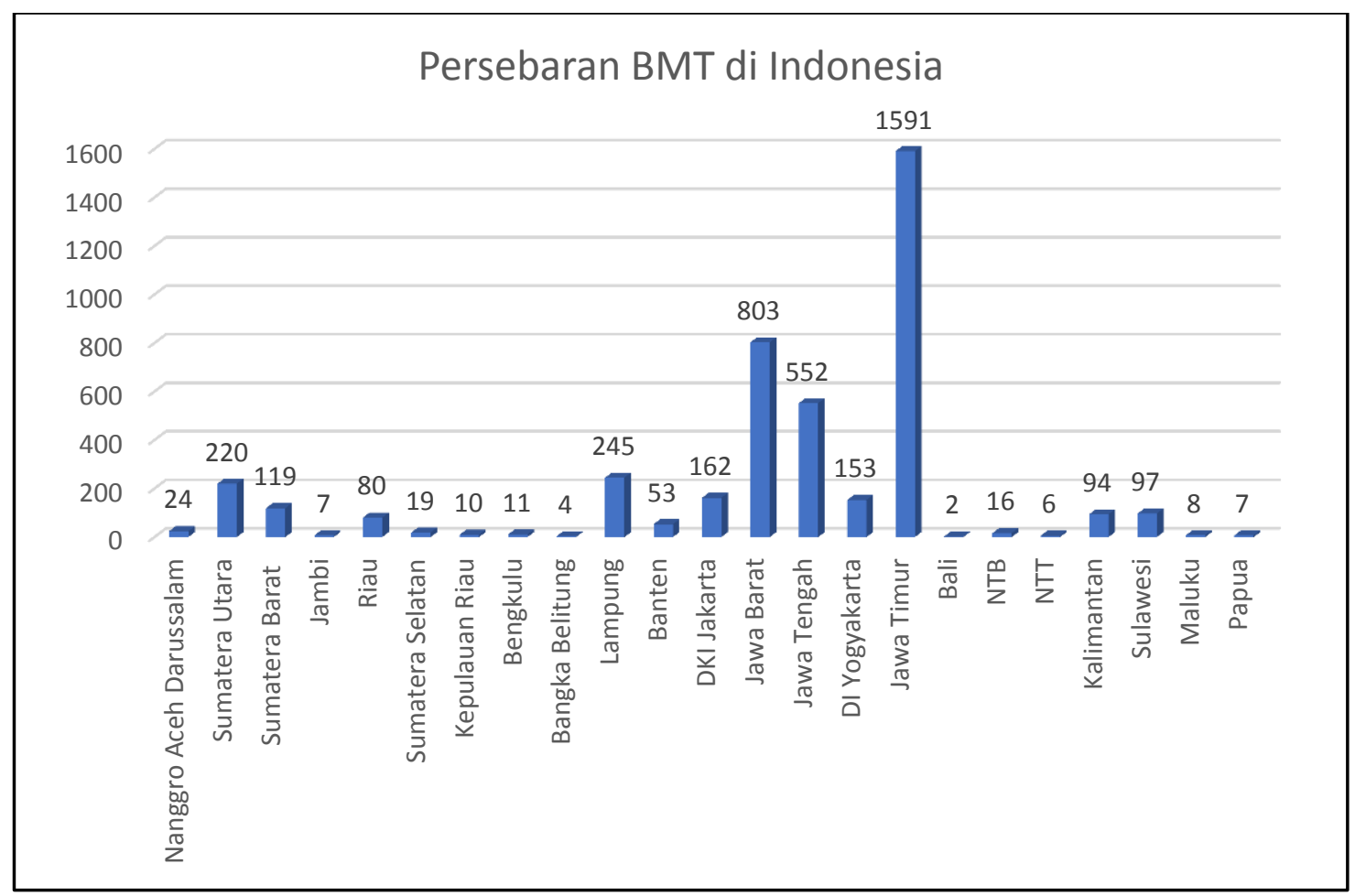

Sumber: Cahyani (2018).

\section{Gambar 3. Persebaran BMT di Indonesia}

\section{KAJIAN TEORITIS}

\section{Financial Technology (Fintech) Syariah}

Fintech (Financial Technology) merupakan inovasi teknologi di bidang jasa keuangan yang tidak memerlukan uang kertas lagi. Fintech telah mengubah pemakaian uang riil menjadi digital, sehingga dianggap lebih efisien. Beberapa literatur mengungkapkan berbagai definisi tentang fintech. Dalam arti luas, fintech merupakan solusisolusi keuangan yang menggunakan teknologi (Douglas, Barberis, \& Buckley, 2015; 
Aaron, Rivadeneyra, \& Sohal, 2017). Fintech syariah diartikan sebagai kombinasi antara teknologi dan sistem keuangan yang memudahkan proses pembiayaan dan transaksi yang menganut nilai-nilai syariah. Meskipun konsep fintech syariah relatif baru di Indonesia, tetapi konsep tersebut telah berkembang pesat. Tujuan fintech syariah seharusnya searah dengan tujuan transaksinya, yaitu untuk memelihara kemaslahatan (kebaikan) dan terhindarkan dari kemudharatan (keburukan), baik di dunia maupun di akhirat (Shidiq, 2016).

\section{Baitul Maal wat Tamwil (BMT)}

Hubungan-hubungan utama yang terjalin dalam unsur-unsur koperasi sebagai organisasi, yaitu hubungan yang terjadi antara anggota-angota perorangan, aktivitas ekonomi usaha rumah tangga anggota, kelompok koperasi, serta hubungan dengan koperasi, baik sebagai lembaga usaha maupun organisasi (Hanel, 1989). Anggota-anggota perorangan yang memiliki minimal satu tujuan bersama, membentuk kelompokkelompok koperasi dan secara bersepakat dan bersama-sama mendirikan koperasi. Anggota-anggota perorangan sebagai anggota koperasi dan memiliki usaha rumah tangga anggota, sehingga terjalin hubungan usaha yang bersifat menunjang antara usaha anggota dengan usaha koperasi, misalnya anggota sebagai konsumen, pemasok, pelanggan, atau pun pengguna jasa koperasi (Hanel, 1989).

Baitul Maal wat Tamwil atau BMT merupakan koperasi yang berbasis syariah dan memiliki dua fungsi utama, yaitu baitul maal atau rumah dana dan baitul tamwil atau rumah usaha (Ridwan, 2004). BMT menghimpun dan menyalurkan dana kepada pelaku usaha yang menguntungkan. Sumber dana Baitul Tamwil berasal dari simpanan masyarakat (dana pihak ketiga) yang meliputi modal, tabungan, simpanan berjangka, dan simpanan lainnya (Soemitra, 2010). Tujuan pendirian BMT adalah membantu kualitas usaha ekonomi, khususnya untuk meningkatkan kesejahteraan anggota dan masyarakat pada umumnya. BMT berusaha memberikan bantuan pembiayaan yang cukup agar mampu memandirikan ekonomi para pelaku usaha mikro. Pada saat memberikan pembiayaan, BMT wajib menciptakan suasana yang transparan, sehingga BMT mampu mendeteksi berbagai kemungkinan yang mucul dari pembiayaan tersebut (Huda \& Heykal, 2010).

\section{Unified Theory of Acceptance and Use of Technology (UTAUT)}

UTAUT merupakan salah satu model penerimaan teknologi yang mensintesiskan elemen-elemen pada delapan model penerimaan teknologi yang pernah ada yaitu theory of reasoned action (TRA) (Vallerand, Deshaies, Cuerrier, Pelletier, \& Mongeau, 1992), technology acceptance model (TAM) (Venkatesh, 2000), motivation model (MM) (Davis, Bagozzi, \& Warshaw, 1992), theory of planned behavior (TPB) (Ajzen, 1991), combined TAM \& TPB (Taylor \& Todd, 1995), model of PC utilization (MPTU) (Thompson et al., 1991 dalam Venkatesh et al., 2003), innovation diffusion theory (IDT) (Moore and Benbasat, 1991 dalam Venkatesh et al., 2003) dan social cognitive theory (SCT) (Compeau and Higgins, 1995 dalam Venkatesh et al., 2003) untuk memperoleh kesatuan pandangan mengenai penerimaan teknologi terkini (Venkatesh et $a l ., 2003)$. UTAUT merupakan sebuah teori dengan empat penentu inti niat dan penggunaan, dan empat moderator hubungan kunci. Hal-hal yang mempengaruhi penerimaan dan perilaku para pengguna teknologi dalam teori ini adalah persepsi mereka terhadap ekspektasi kinerja, ekspektasi usaha, pengaruh sosial, dan kondisi yang mendukung. 
Model UTAUT adalah teori yang banyak diadopsi oleh penelitian-penelitian tentang penerimaan pengguna terhadap teknologi yang digunakan.

Ekspektasi kinerja merupakan harapan individu yang menggunakan teknologi tertentu apabila ia akan mendapatkan manfaat pada aktivitas yang dilakukannya sebagai pengguna teknologi tersebut (Venkatesh et al., 2003). Penelitian empiris menunjukkan bahwa peningkatan ekspektasi kinerja akan meningkatkan kemungkinan niat untuk mengadopsi mobile banking (Gupta, Manrai, \& Goel, 2019). Variabel ekspektasi kinerja mencerminkan peningkatan efisiensi dan kenyamanan pembayaran saat menggunakan mobile banking. Persepsi individu menunjukkan bahwa penggunaan layanan pembayaran dari bank akan membantu mencapai keuntungan pelaksanaan tugas pembayaran, sehingga layanan tersebut dapat mempengaruhi niat perilaku untuk mengadopsinya (Zhou, Lu, \& Wang, 2010). Dari uraian tersebut, maka penelitian ini akan menguji hipotesis kesatu (H1) sebagai berikut:

\section{H1: Ekspektasi kinerja berpengaruh positif terhadap niat perilaku menggunakan Itqan Mobile.}

Ekspektasi usaha diartikan sebagai tingkat kepercayaan seseorang bahwa menggunakan sistem itu mudah (Venkatesh et al., 2003). Pelanggan menganggap ekspektasi kinerja dan ekspektasi usaha sebagai faktor penting yang mempengaruhi kemungkinan penggunaan M-banking mereka (Farah, Hasni, \& Abbas, 2018). Penelitian terdahulu menunjukkan bahwa ekspektasi usaha berpengaruh signifikan dan memberikan hasil positif (Martins, Oliveira, \& Popovic, 2014). Dari uraian tersebut, maka penelitian ini akan menguji hipotesis kedua (H2) sebagai berikut:

\section{H2: Ekspektasi usaha berpengaruh positif terhadap niat perilaku menggunakan Itqan Mobile.}

Pengaruh sosial menunjukkan seberapa pentingnya pengaruh orang-orang di sekitar pengguna teknologi untuk membantu memutuskan penggunaan sebuah teknologi (Venkatesh et al., 2003). Pemilihan pengaruh sosial sebagai penentu utama niat perilaku didasarkan pada kenyataan bahwa pelanggan dipengaruhi oleh ketidakpastian terkait dengan layanan inovatif, seperti pembayaran bank yang akan memaksa mereka untuk berinteraksi dengan orang-orang di jejaring sosial mereka guna berkonsultasi mengenai keputusan penggunaan mereka (Oliveira, Thomas, \& Baptista, 2016). Hubungan dianggap sebagai aspek penting perilaku manusia dalam konteks masyarakat di India, pembayaran bank oleh pelanggan sangat dipengaruhi oleh teman, rekan kerja, dan keluarga mereka (Gupta et al., 2019). Dari uraian tersebut, maka penelitian ini akan menguji hipotesis ketiga (H3) sebagai berikut:

\section{H3: Pengaruh sosial berpengaruh positif terhadap niat perilaku menggunakan Itqan Mobile.}

Kondisi yang mendukung menentukan seberapa penting fasilitas yang diberikan oleh sebuah teknologi untuk mendorong seseorang menggunakannya (Venkatesh et al., 2003). Kondisi yang mendukung menjelaskan pada persepsi konsumen tentang sumber daya dan dukungan yang ada untuk melakukan suatu perilaku. Kondisi yang mendu- 
kung memiliki kemiripan dengan persepsi kontrol perilaku yang mencerminkan efek pengetahuan, kemampuan, dan sumber daya pengguna (Venkatesh, Thong, \& Xu, 2012). Pengalaman yang lebih banyak diperlukan untuk memberikan fasilitas proses pembelajaran kepada pengguna agar mereka mampu mendorong teknologi dan pengetahuan yang lebih baik (Zhou et al., 2010). Variabel kondisi yang mendukung mencerminkan sumber daya dan pengetahuan yang dimiliki oleh pengguna (Kwateng, Atiemo, \& Appiah, 2018). Dari uraian tersebut, maka penelitian ini akan menguji hipotesis keempat (H4) sebagai berikut:

\section{H4: Kondisi yang mendukung berpengaruh positif terhadap niat perilaku menggunakan Itqan Mobile.}

Niat perilaku diartikan sebagai keinginan seseorang untuk melakukan suatu perilaku tertentu (Venkatesh et al., 2003). Niat perilaku menjadi faktor motivasi yang mengukur seberapa banyak usaha yang ingin dilakukan oleh seseorang untuk berperila$\mathrm{ku}$ (Ajzen, 1991). Niat konsumen memiliki keunikan sebagai faktor yang menunjukkan peran penting tambahan dalam perilaku konsumen. Sebuah studi empiris tentang niat konsumen menghasilkan landasan penting untuk memprediksi perilaku aktual konsumen pada tindakan tertentu (Mamman, Ogunbado, \& Abu-Bakr, 2016). Dari uraian tersebut, maka penelitian ini akan menguji hipotesis kelima (H5) sebagai berikut:

H5: Niat perilaku berpengaruh positif terhadap perilaku pengguna Itqan Mobile.

Perilaku penggunaan teknologi secara aktual (actual system usage) adalah tindakan menggunakan teknologi yang sesungguhnya dilakukan oleh seorang pengguna teknologi (Venkatesh et al., 2003). Perilaku pengguna adalah respon nyata, teramati dalam situasi tertentu sehubungan dengan target yang diberikan (Ajzen, 1991). Dengan memahami faktor-faktor yang mempengaruhi adopsi pengguna dan penggunaan layanan mobile banking, bank dapat menargetkan kendala yang menghambat adopsi pengguna dan meningkatkan layanan mereka (Zhou et al., 2010). Di antara faktor-faktor yang mempengaruhi adopsi pengguna, pengaruh ekspektasi kinerja relatif besar. Karena itu, ketika bank mengembangkan fungsi mobile banking, mereka perlu mempertimbangkan harapan pengguna terhadap fungsi-fungsi tersebut (Zhou et al., 2010). Dari uraian tersebut, maka penelitian ini akan menguji hipotesis keenam (H6) sebagai berikut:

\section{H6: Ekspektasi kinerja berpengaruh positif terhadap perilaku pengguna Itqan Mobile.}

Berdasarkan actual system usage (Venkatesh et al., 2003), variabel ekspektasi usaha mencerminkan kemudahan belajar untuk menggunakan mobile banking dengan trampil (Zhou et al., 2010). Jika pengguna menemukan layanan internet banking yang mudah digunakan, maka mereka lebih cenderung untuk menggunakan dan mengadopsinya. Sebaliknya, jika pengguna menemukan layanan internet banking yang sulit digunakan, maka mereka cenderung untuk tidak mengadopsinya (Tarhini, El-Masri, Ali, \& Serrano, 2015). Dari uraian tersebut, maka penelitian ini akan menguji hipotesis ketujuh (H7) sebagai berikut: 


\section{H7: Ekspektasi usaha berpengaruh positif terhadap perilaku pengguna Itqan Mobile.}

Variabel pengaruh sosial menunjukkan betapa pentingnya pengaruh dari orangorang sekitar yang menentukan perilaku penggunaan teknologi (Zhou et al., 2010). Konsumen sangat dipengaruhi oleh ketidakpastian yang diciptakan dari sebuah inovasi, seperti mobile banking dan hal itu akan memaksa mereka untuk berinteraksi dengan jejaring sosial untuk berkonsultasi tentang keputusan adopsi mereka (Tarhini et al., 2015). Dari uraian tersebut, maka penelitian ini akan menguji hipotesis kedelapan (H8) sebagai berikut:

\section{H8: Pengaruh sosial berpengaruh positif terhadap perilaku pengguna Itqan Mobile.}

Variabel kondisi yang mendukung mencerminkan sumber daya dan pengetahuan para penggunanya (Zhou et al., 2010). Banyak konsumen menolak untuk menggunakan teknologi secara sukarela karena mereka harus memberikan informasi sensitif melalui internet, padahal mereka tidak memiliki kendali atas perilaku mereka sendiri. Mereka memberikan saran bahwa pembuat kebijakan seharusnya memperhatikan masalah privasi, keamanan, dan kepercayaan dengan serius pada saat menerapkan sistem online. Oleh karena itu, sangat penting bagi pengguna untuk percaya bahwa transaksi perbankannya dapat diselesaikan secara rahasia dan aman melalui internet (Tarhini et al., 2015). Dari uraian tersebut, maka penelitian ini akan menguji hipotesis kesembilan (H9) sebagai berikut:

\section{H9: Kondisi yang mendukung berpengaruh positif terhadap perilaku pengguna Itqan Mobile.}

Variabel ekspektasi kinerja berpengaruh signifikan dan positif terhadap niat perilaku (Martins et al., 2014; Farah et al., 2018; Gupta et al., 2019). Kemudian hasil penelitian empiris menunjukkan bahwa variabel ekspektasi kinerja berpengaruh signifikan dan positif terhadap perilaku pengguna (actual usage) (Zhou et al., 2010; Tarhini et al., 2015). Dari uraian tersebut, maka penelitian ini akan menguji hipotesis kesepuluh (H10) sebagai berikut:

H10: Ekspektasi kinerja berpengaruh secara tidak langsung terhadap perilaku pengguna Itqan Mobile melalui niat perilaku menggunakan Itqan Mobile sebagai variabel intervening.

Penelitian terdahulu menunjukkan ekspektasi usaha berpengaruh signifikan dan hasil positif terhadap niat perilaku (Martins et al., 2014; Warsame \& Ireri, 2018; Farah et al., 2018). Kemudian hasil penelitian memberikan hasil signifikan dan positif terhadap perilaku pengguna (actual usage) (Tarhini et al., 2015). Dari uraian tersebut, maka penelitian ini akan menguji hipotesis kesebelas (H11) sebagai berikut: 
H11: Ekspektasi usaha berpengaruh secara tidak langsung terhadap perilaku pengguna Itqan Mobile melalui niat perilaku menggunakan Itqan Mobile sebagai variabel intervening.

Pengaruh sosial menunjukkan pengaruh dari orang lain memiliki arti penting bagi perilaku pengguna $m$-banking. Hasil penelitian memberikan hasil signifikan dan positif terhadap niat perilaku pengguna (Zhou et al., 2010; Martins et al., 2014; Farah et al., 2018). Kemudian hasil penelitian berpengaruh signifikan dan positif terhadap perilaku pengguna (actual usage) (Zhou et al., 2010; Tarhini et al., 2015). Dari uraian tersebut, maka penelitian ini akan menguji hipotesis kedua belas (H12) sebagai berikut:

\section{H12: Pengaruh sosial berpengaruh secara tidak langsung terhadap perilaku pengguna Itqan Mobile melalui niat perilaku menggunakan Itqan Mobile sebagai variabel intervening.}

Menggunakan mobile banking dan pembayaran mobile biasanya memerlukan jenis ketrampilan, sumber daya, dan infrastruktur teknis tertentu. Hasil penelitian terdahulu menunjukkan bahwa kondisi yang mendukung berpengaruh secara signifikan dan positif terhadap tindakan pengguna (Zhou et al., 2010; Oliveira et al., 2016; Gupta et al., 2019). Kemudian hasil penelitian berpengaruh signifikan dan positif terhadap perilaku pengguna (Zhou et al., 2010; Tarhini et al., 2015; Oliveira et al., 2016; Alalwana, Dwivedib, \& Ranab, 2017;Gupta et al., 2019). Dari uraian tersebut, maka penelitian ini akan menguji hipotesis ketiga belas (H13) sebagai berikut:

H13: Kondisi yang mendukung berpengaruh secara tidak langsung terhadap perilaku pengguna Itqan Mobile melalui niat perilaku menggunakan Itqan Mobile sebagai variabel intervening.

Model UTAUT memiliki kemampuan prediksi yang akurat tentang niat nasabah perbankan untuk mengadopsi mobile banking (Farah et al., 2018). Sejalan dengan Farah et al. (2018), secara teoritis maupun empiris kemampuan model UTAUT menjadi rerangka kerja teoritis untuk lebih memahami penerimaan pelanggan terhadap internet banking (Tarhini et al., 2015). Dalam penelitian ini, model UTAUT dipilih karena model tersebut dianggap paling tepat untuk membuktikan pengaruh variabel ekspektasi kinerja, ekspektasi usaha, pengaruh sosial, dan kondisi yang mendukung terhadap perilaku pengguna Itqan Mobile di BMT Itqan melalui niat perilaku sebagai variabel mediasi (intervening).

Berbeda dari model asalnya, penelitian ini menguji model UTAUT tanpa menggunakan variabel moderatornya, yaitu gender, usia, pengalaman, dan kesukarelaan menggunakan. Beberapa penelitian terdahulu menggunakan analisis model UTAUT tanpa menggunakan variabel moderatornya (Gupta et al., 2019; Hamrul, Soedijono, \& Amborowati, 2013; Hamrul et al., 2013; Islam, Karia, Khaleel, Fauzi, Soliman, Khalid, \& Mamun, 2019). Ada pun beberapa penelitian mengenai jenis kelamin (Laukkanen \& Pasanen, 2008; Kautonen, Luoto, \& Tornikoski, 2010; Altawallbeh, Thiam, Alshourah, \& Fong, 2015), usia (Laukkanen \& Pasanen, 2008; Kautonen et al., 2010; Altawallbeh et al., 2015), pengalaman (Pituch \& Lee,2006; DeGennaro, 2010; Abbasi, Chandio, 
Soomro, \& Shah, 2011; Altawallbeh et al., 2015), dan penambahan variabel baru yaitu latar belakang pendidikan yang dianggap penting untuk mengukur niat perilaku menggunakan mobile banking (Schleife, 2010; Sipior, Ward, \& Connolly, 2011; Rahman, 2015) berpengaruh terhadap niat perilaku.

\section{METODE PENELITIAN}

Obyek penelitian ini adalah BMT Itqan yang berada di Kota Bandung. Data awal dalam penelitian ini bersumber dari hasil wawancara pra-survei dengan pimpinan bidang keuangan BMT Itqan yang menyatakan bahwa jumlah anggotanya sudah mencapai 9.966 orang, tetapi jumlah anggota yang telah menggunakan layanan Itqan Mobile pada tahun 2018 baru mencapai 276 orang anggota. Jumlah ini terhitung masih sangat sedikit dibandingkan dengan total jumlah anggota BMT Itqan. Fenomena inilah yang memicu arti penting penelitian ini untuk menguji penerimaan teknologi oleh anggota BMT Itqan berdasarkan model UTAUT dan memberikan dasar analisis teoritis mengapa hal itu terjadi.

Penelitian ini menggunakan pendekatan kuantitatif. Anggota BMT Itqan menjadi populasi, sedangkan metode sampling yang digunakan dalam penelitian ini adalah probability sampling karena semua anggota BMT Itqan memiliki kesempatan yang sama dipilih sebagai sampel (Sekaran \& Bougie, 2017). Prosedur pengambilan sampel terbagi menjadi dua kelompok. Anggota BMT Itqan yang sudah menggunakan maupun yang belum menggunakan Itqan Mobile. Penentuan jumlah sampel dalam penelitian ini didasarkan pada jumlah populasi dan sampel pada Tabel 1.

Tabel 1. Penentuan Jumlah Sampel

\begin{tabular}{rrrrrr}
\hline Populasi & Sampel & Populasi & Sampel & Populasi & Sampel \\
\hline 10 & 10 & 290 & 165 & 1.200 & 291 \\
\hline 15 & 14 & 300 & 169 & 1.300 & 297 \\
120 & 92 & 360 & 186 & 8.000 & 367 \\
\hline 130 & 97 & 380 & 191 & 9.000 & 368 \\
\hline 140 & 103 & 400 & 196 & $\mathbf{1 0 . 0 0 0}$ & $\mathbf{3 7 0}$ \\
\hline
\end{tabular}

Keterangan: Populasi=N; Sampel=n.

Sumber: Sekaran \& Bougie (2017).

Berdasarkan Tabel 1 tersebut, jumlah populasi dalam penelitian ini adalah seluruh anggota BMT Itqan Bandung sebanyak 9.966 orang anggota. Karena jumlah populasi tersebut mendekati angka 10.000, maka jumlah sampel yang menjadi sasaran dalam penelitian ini adalah 370 anggota BMT Itqan, baik yang sudah menggunakan maupun yang belum menggunakan Itqan Mobile. Untuk menentukan proporsi jumlah sampel untuk setiap kategori digunakan probability stratified samples, yaitu teknik sampling yang digunakan bagi populasi yang memiliki anggota/unsur yang tidak homogen dan berstrata secara proporsional (Sugiyono, 2016). Sebelum pengambilan sampel, populasi dibagi menjasi dua sub-populasi, yaitu anggota yang menggunakan dan anggota yang belum menggunakan. Perhitungan proporsi dan jumlah sampel yang digunakan dalam penelitian ini ditunjukkan pada Tabel 2.

Teknik pengumpulan data primer yang digunakan dalam penelitian ini adalah survei dengan menggunakan kuesioner. Data primer diartikan sebagai data yang diperoleh 
secara langsung dari sumber aslinya yaitu responden (Sugiyono, 2017). Penyebaran kuesioner menggunakan cara online dan offline. Penyebaran kuesioner dengan cara online dilakukan menggunakan smartphone dengan mengakses Google Form yang telah disediakan, sedangkan cara offline dilakukan dengan mengisi lembar kuesioner secara langsung oleh responden. Kedua form kuesioner, baik online maupun offline didisain dengan format dan konten yang sama.

Tabel 2. Penentuan Jumlah Sampel

\begin{tabular}{lccc}
\hline \multicolumn{1}{c}{ Keterangan } & $\begin{array}{c}\text { Perhitungan Sampel } \\
\text { secara Proporsional }\end{array}$ & $\begin{array}{c}\text { Sampel Hasil } \\
\text { Perhitungan }\end{array}$ & $\begin{array}{c}\text { Pembulatan } \\
\text { Jumlah } \\
\text { Sampel yang } \\
\text { Digunakan }\end{array}$ \\
\hline $\begin{array}{l}\text { Menggunakan Itqan Mobile } \\
\text { (Kelompok 1) }\end{array}$ & $\frac{276}{9.966}$ X 370 & 10,22 & 10 \\
\hline $\begin{array}{l}\text { Belum menggunakan Itqan Mobile } \\
\text { (Kelompok 2) }\end{array}$ & $370-10$ & 360,00 & 360 \\
\hline & Jumlah Sampel Digunakan & & $\mathbf{3 7 0}$ \\
\hline
\end{tabular}

Sumber: Hasil Pengolahan Data (2020).

Tabel 3. Definisi Operasional Variabel Penelitian

\begin{tabular}{|c|c|c|c|}
\hline Variabel & Definisi & Indikator Pengukuran & Skala \\
\hline $\begin{array}{l}\text { Ekspektasi } \\
\text { Kinerja (X1) }\end{array}$ & $\begin{array}{l}\text { Ekspektasi kinerja merupakan } \\
\text { dimana individu akan mau } \\
\text { menggunakan teknologi tertentu } \\
\text { jika dapat memberikan manfaat } \\
\text { pada aktivitas yang dilakukan } \\
\text { pengguna. }\end{array}$ & $\begin{array}{l}\text { - Persepsi kegunaan. } \\
\text { - Motivasi ekstrinsik. } \\
\text { - Kesesuaian pekerjaan. } \\
\text { - Keuntungan relatif. } \\
\text { - Ekspektasi hasil. }\end{array}$ & Ordinal \\
\hline $\begin{array}{l}\text { Ekspektasi } \\
\text { Usaha (X2) }\end{array}$ & $\begin{array}{l}\text { Ekspektasi usaha diartikan sebagai } \\
\text { keinginan individu menggunakan } \\
\text { teknologi terbaru karena mudah } \\
\text { pemakaiannya. }\end{array}$ & $\begin{array}{l}\text { - Persepsi kemudahan } \\
\text { penggunaan. } \\
\text { - Kompleksitas. } \\
\text { - Kemudahan penggunaan. }\end{array}$ & Ordinal \\
\hline $\begin{array}{l}\text { Pengaruh Sosial } \\
\text { (X3) }\end{array}$ & $\begin{array}{l}\text { Pengaruh sosial diartikan pengaruh } \\
\text { orang-orang sekitar sangat penting } \\
\text { untuk mempengaruhi kita untuk } \\
\text { menggunakan teknologi. }\end{array}$ & $\begin{array}{l}\text { - Norma subjektif. } \\
\text { - Faktor sosial. } \\
\text { - Image. }\end{array}$ & Ordinal \\
\hline $\begin{array}{l}\text { Kondisi yang } \\
\text { Mendukung (X4) }\end{array}$ & $\begin{array}{l}\text { Kondisi yang mendukung diartikan } \\
\text { pentingnya fasilitas yang } \\
\text { mendukung suatu teknologi agar } \\
\text { mampu mendorong perilaku } \\
\text { seseorang untuk menggunakannya. }\end{array}$ & $\begin{array}{l}\text { - Persepsi kontrol perilaku. } \\
\text { - Kondisi yang mendukung. } \\
\text { - Kesesuaian. }\end{array}$ & Ordinal \\
\hline $\begin{array}{l}\text { Niat Perilaku } \\
\text { menggunakan } \\
\text { Itqan Mobile } \\
\text { (Y) }\end{array}$ & $\begin{array}{l}\text { Niat perilaku adalah keinginan } \\
\text { seseorang saat ingin melakukan } \\
\text { sesuatu yang diinginkannya. }\end{array}$ & $\begin{array}{l}\text { - Selalu mencoba } \\
\text { menggunakan. } \\
\text { - Akan menggunakan lebih } \\
\text { sering. } \\
\text { - Berlanjut di masa datang. }\end{array}$ & Ordinal \\
\hline $\begin{array}{l}\text { Perilaku } \\
\text { Pengguna Itqan } \\
\text { Mobile (Z) }\end{array}$ & $\begin{array}{l}\text { Perilaku penggunaan teknologi } \\
\text { sesunguhnya adalah tindakan } \\
\text { menggunakan teknologi } \\
\text { sesungguhnya yang dilakukan } \\
\text { seorang pemakai teknologi. }\end{array}$ & - Durasi penggunaan. & Ordinal \\
\hline
\end{tabular}

Sumber: Venkatesh et al. (2003). 
Dua cara tersebut digunakan dengan tujuan untuk memperbesar response rate, karena responden dapat memilih cara pengisian kuesioner mana yang lebih nyaman bagi mereka. Selanjutnya, seluruh kuesioner yang terkumpul dilakukan rekapitulasi ke dalam worksheet. Skala pengukuran yang digunakan dalam penelitian ini menggunakan skala Likert (skala 1-5). Skala Likert digunakan untuk mengukur sikap, pendapat dan persepsi seseorang atau sekelompok orang tentang fenomena sosial (Sugiyono, 2016).

Analisis yang digunakan dalam penelitian ini regresi linear berganda untuk menentukan peran masing-masing variabel independen berdasarkan UTAUT terhadap variabel dependen dan analisis jalur (path analysis) untuk menentukan apakah variabel independen memiliki peran terhadap variabel dependen melalui variabel mediasi (intervening). Analisis jalur adalah penggunaan analisis regresi untuk menaksir hubungan kausalitas antarvariabel yang telah ditetapkan sebelumnya berdasarkan teori. Analisis jalur tidak dapat menentukan hubungan sebab akibat dan juga tidak dapat digunakan sebagai substitusi untuk melihat hubungan kausal antarvariabel (Ghozali, 2016). Penelitian ini menggunakan uji regresi sebanyak dua kali, yaitu model persamaan regresi I untuk menguji pengaruh variabel independen (Xn) terhadap variabel dependen (Y). Selanjutnya, model persamaan regresi II untuk menguji pengaruh variabel independen $(\mathrm{Xn})$ terhadap variabel dependen (Z). Analisis regresi linier berganda dalam penelitian ini menggunakan bantuan aplikasi Statistical Product and Service Solutions (SPSS) versi 25. Tabel 3 menunjukkan definisi operasional variabel-variabel yang digunakan dalam penelitian ini. Gambar 4 menunjukkan model UTAUT rancangan Venkatesh et al. (2003) yang telah dimodifikasi sesuai tujuan penelitian ini.

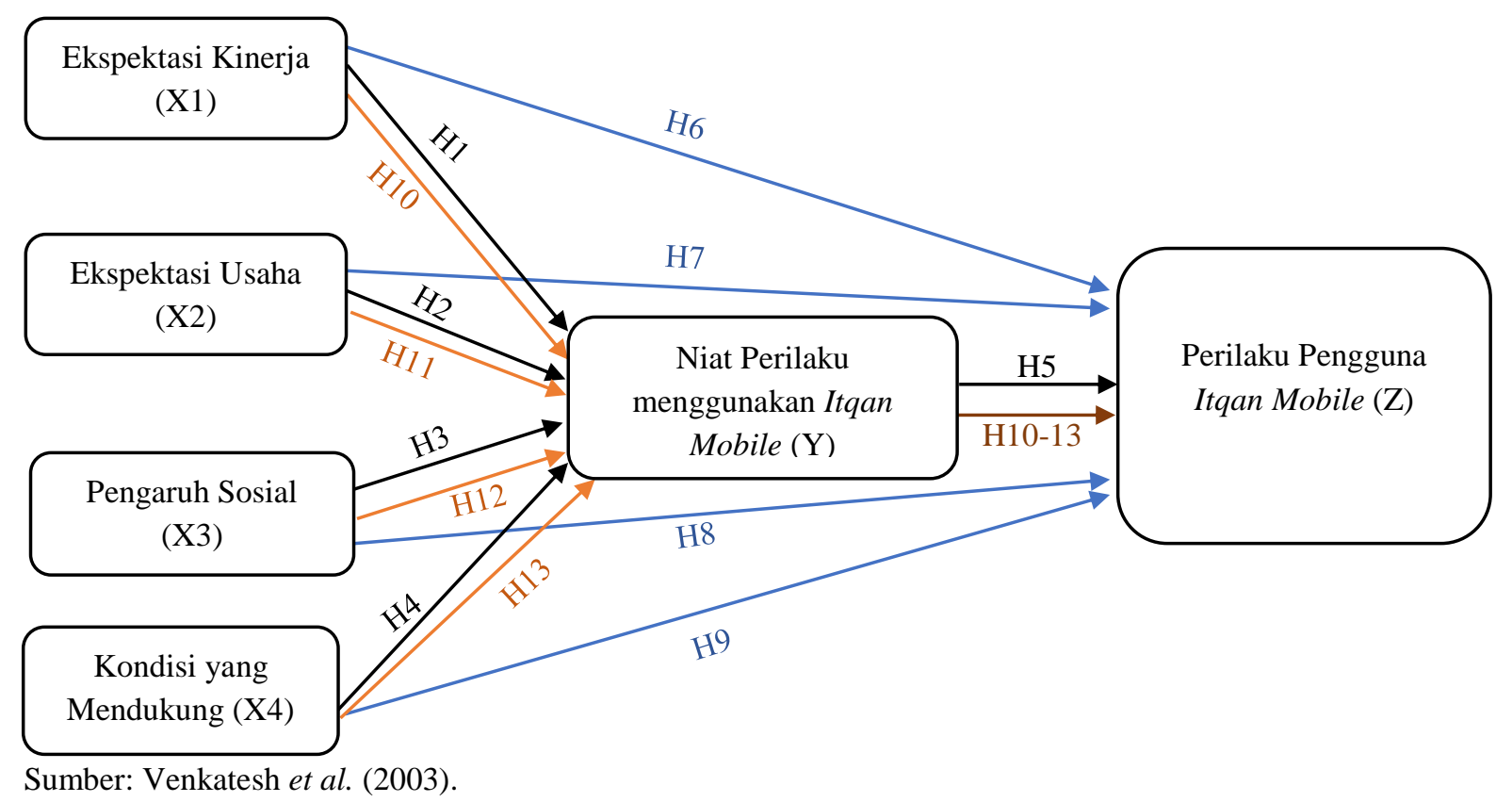

Gambar 4. Model The Unified Theory of Acceptance and Use of Technology (UTAUT) yang Dimodifikasi 


\section{HASIL DAN PEMBAHASAN}

\section{Hasil Analisis Data}

\section{Diskripsi Obyek Penelitian}

Berdasarkan hasil observasi pra-survei di Kota Bandung, salah satu BMT yang telah memiliki fintech berupa layanan mobile banking adalah BMT Itqan yang beralamat di Jalan Padasuka nomor 160 Kota Bandung, Provinsi Jawa Barat. Aplikasi teknologinya bernama Itqan Mobile. Aplikasi ini didisain untuk meningkatkan layanan yang memudahkan anggota dalam kegiatan transaksi keuangan elektronik dan sangat mudah diunduh dan digunakan melalui smartphone. Fitur-fitur yang diberikan meliputi informasi simpanan, ziswaf (zakat, infaq, shadaqah, dan wakaf), transfer, mutasi simpanan, riwayat pinjaman, saldo deposito, pembelian, dan pembayaran tagihan, seperti PLN (Perusahaan Listrik Negara), BPJS (Badan Penyelenggara Jaminan Sosial), Telkom (Telekomunikasi), dan lain-lain. Itqan Mobile sudah diperkenalkan sejak tahun 2015, tetapi layanan ini aktif kembali sejak diperbarui tahun 2017, sehingga aplikasinya relatif lebih baru untuk melayani penggunanya di BMT Itqan.

Pada tahun 2018, jumlah anggota BMT Itqan telah mencapai 9.966 orang (Gambar 5). Berdasarkan wawancara pra-survei dengan Kepala Bidang Keuangan BMT Itqan yang menyatakan meskipun jumlah anggota BMT Itqan sudah melebihi 9.000 orang anggota, tetapi jumlah anggota yang telah menggunakan Itqan Mobile baru mencapai 276 orang anggota pada tahun 2018. Namun, pemakai Itqan Mobile mengalami peningkatan mencapai 394 anggota pada bulan September 2019. Jumlah ini masih relatif lebih sedikit dibandingkan dengan keseluruhan jumlah anggota BMT Itqan.

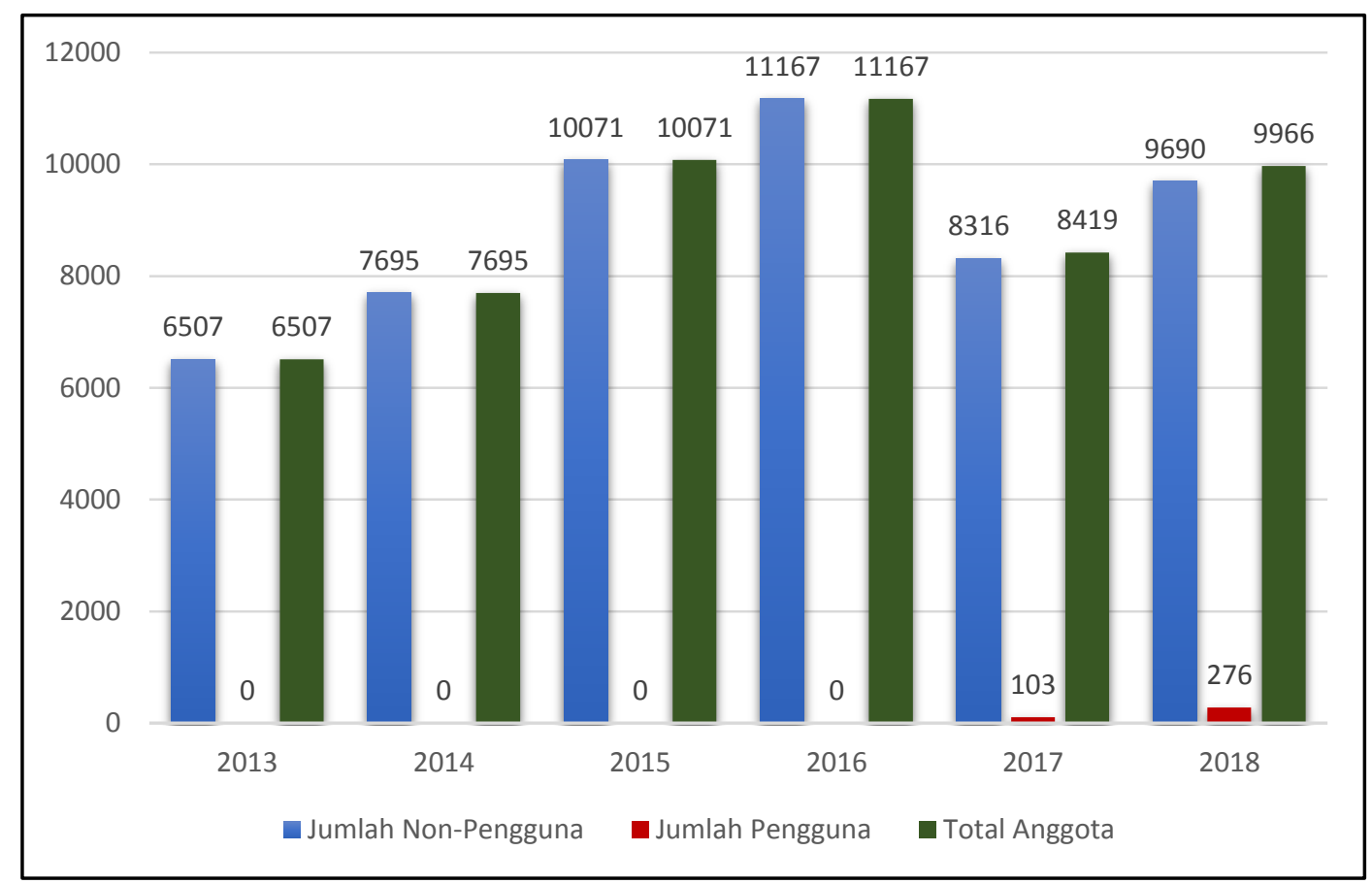

Sumber: BMT Itqan (2018).

Gambar 5. Jumlah Anggota BMT Itqan tahun 2013-2018 


\section{Hasil Uji Validitas dan Reliabilitas Instrumen Penelitian}

Uji validitas dilakukan pada seluruh pertanyaan bertujuan untuk menguji seberapa valid setiap pertanyaan yang digunakan di dalam kuesioner. Teknik uji validitas yang digunakan adalah teknik uji korelasi Pearson Product Moment (Arikunto, 2016). Hasil uji validitas variabel ekspektasi kinerja, ekspektasi usaha, pengaruh sosial, kondisi yang mendukung, niat perilaku, dan perilaku pengguna menunjukkan bahwa masing-masing pertanyaan setiap variabel dinyatakan valid, sehingga data yang telah terkumpul dalam penelitian ini layak untuk dianalisis lebih lanjut. Pengambilan kesimpulan pengujian bahwa model penelitian ini dikatakan valid didasarkan pada nilai R-hitung lebih besar daripada R-tabel (Tabel 5).

Tabel 5. Hasil Pengujian Validitas

\begin{tabular}{cccc}
\hline Variabel & Nilai R-hitung & Nilai R-tabel & Keputusan \\
\hline Ekspektasi Kinerja & 0,613 & 0,138 & Valid \\
\hline Ekspektasi Usaha & 0,561 & 0,138 & Valid \\
\hline Pengaruh Sosial & 0,618 & 0,138 & Valid \\
\hline Kondisi yang Mendukung & 0,584 & 0,138 & Valid \\
\hline Niat Perilaku Menggunakan & 0,807 & 0,138 & Valid \\
\hline Perilaku Pengguna & 0,772 & 0,138 & Valid \\
\hline
\end{tabular}

Sumber: Data primer diolah (2019).

Uji reliabilitas dalam penelitian ini menggunakan metode Cronbach alpha. Pengujian reliabilitas dilakukan secara bersama-sama terhadap seluruh butir pertanyaan pada kuesioner penelitian. Apabila korelasinya menunjukkan angka lebih dari 0,7, maka butir pertanyaan dinyatakan reliabel (Ghozali, 2016). Namun, apabila hasilnya menunjukkan sebaliknya, yaitu nilai korelasinya menunjukkan angka kurang dari 0,7, maka butir pertanyaan dinyatakan tidak reliabel. Perhitungan uji reliabilitas pada seluruh butir pertanyaan menunjukkan bahwa instrumen variabel ekspektasi kinerja, ekspektasi usaha, pengaruh sosial, kondisi yang mendukung, niat perilaku menggunakan, dan perilaku pengguna dinyatakan andal atau reliabel (Tabel 6).

Tabel 6. Hasil Pengujian Realibilitas

\begin{tabular}{lccc}
\hline \multicolumn{1}{c}{ Variabel } & $\begin{array}{c}\text { Jumlah } \\
\text { indikator }\end{array}$ & $\begin{array}{c}\text { Cronbach's } \\
\text { Alpha }\end{array}$ & Keputusan \\
\hline Ekspektasi Kinerja & 5 & 0,817 & Reliabel \\
\hline Ekspektasi Usaha & 3 & 0,828 & Reliabel \\
\hline Pengaruh Sosial & 3 & 0,826 & Reliabel \\
\hline Kondisi Yang Memfasilitasi & 3 & 0,802 & Reliabel \\
\hline Niat Perilaku & 3 & 0,861 & Reliabel \\
\hline Perilaku Pengguna & 1 & 0,857 & Reliabel \\
\hline
\end{tabular}

Sumber: Data primer diolah (2019).

\section{Pengujian Hipotesis}

Pengujian hipotesis pada penelitian ini merupakan hasil analisis regresi linear berganda dan analisis jalur. Analisis regresi dilakukan, baik untuk menentukan pengaruh langsung maupun tidak langsung. Pengujian hipotesis dilakukan dengan menggunakan 
uji t (pengaruh parsial) dan pengambilan kesimpulan hipotesisnya berdasarkan kriteria jika nilai signifikansi lebih kecil daripada 0,50 , maka Hn diterima. Sebaliknya, jika nilai signifikansi lebih besar daripada 0,50, maka Hn ditolak (Ghozali, 2016).

Berdasarkan hasil pengujian hipotesis berdasarkan pengaruh langsung, data pada Tabel 7 menunjukkan bahwa variabel ekspektasi usaha (X2) secara parsial memiliki peran menentukan niat perilaku menggunakan Itqan Mobile (Y), sedangkan variabel ekspektasi kinerja (X1), pengaruh sosial (X3), dan kondisi yang mendukung (X4) secara parsial tidak memiliki peran terhadap pembentukan niat perilaku menggunakan Itqan Mobile. Selanjutnya, variabel ekspektasi kinerja (X1), ekspektasi usaha (X2), dan niat perilaku menggunakan Itqan Mobile (Y) secara parsial juga tidak memiliki peran terhadap perilaku pengguna Itqan Mobile. Namun, pengaruh sosial (X3) dan kondisi yang mendukung (X4) secara parsial memiliki peran penting untuk menentukan perilaku pengguna Itqan Mobile.

Tabel 7. Hasil Pengujian Hipotesis Pengaruh Langsung

\begin{tabular}{cccc}
\hline Hipotesis & Jalur & Nilai Sig. & Kesimpulan Hipotesis (Hn) \\
\hline $\mathrm{H} 1$ & $\mathrm{X} 1 \longrightarrow \mathrm{Y}$ & .081 & Ditolak \\
$\mathrm{H} 2$ & $\mathrm{X} 2 \longrightarrow \mathrm{Y}$ & .000 & Diterima \\
$\mathrm{H} 3$ & $\mathrm{X} 3 \longrightarrow \mathrm{Y}$ & .501 & Ditolak \\
\hline $\mathrm{H} 4$ & $\mathrm{X} 4 \longrightarrow \mathrm{Y}$ & .302 & Ditolak \\
$\mathrm{H} 5$ & $\mathrm{Y} \longrightarrow \mathrm{Z}$ & .236 & Ditolak \\
\hline $\mathrm{H} 6$ & $\mathrm{X} 1 \longrightarrow \mathrm{Z}$ & .330 & Ditolak \\
\hline $\mathrm{H} 7$ & $\mathrm{X} 2 \longrightarrow \mathrm{Z}$ & .533 & Ditolak \\
$\mathrm{H} 8$ & $\mathrm{X} 3 \longrightarrow \mathrm{Z}$ & .000 & Diterima \\
\hline $\mathrm{H} 9$ & $\mathrm{X} 4 \longrightarrow \mathrm{Z}$ & .002 & Diterima \\
\hline $\mathrm{Pu}$ & & & \\
\hline
\end{tabular}

Sumber: Data primer diolah (2019).

Pengujian analisis jalur dilakukan untuk menentukan peran niat perilaku menggunakan Itqan Mobile (Y) sebagai variabel mediasi (intervening variable) yang menentukan pengaruh variabel ekspektasi kinerja (X1), ekspektasi usaha (X2), pengaruh sosial (X3), dan kondisi yang mendukung (X4) secara parsial dan tidak langsung terhadap perilaku pengguna Itqan Mobile. Hasil pengujian tersebut menunjukkan bahwa ekspektasi kinerja, ekspektasi usaha, pengaruh sosial dan kondisi yang mendukung memiliki pengaruh secara tidak langsung terhadap perilaku pengguna Itqan Mobile melalui niat perilaku menggunakan Itqan Mobile (Tabel 8).

Tabel 8. Hasil Pengujian Hipotesis Pengaruh Tidak Langsung

\begin{tabular}{|c|c|c|c|c|c|}
\hline \multirow{2}{*}{ Hipotesis } & \multirow{2}{*}{ Jalur } & \multicolumn{3}{|c|}{ Pengaruh } & \multirow{2}{*}{$\begin{array}{c}\text { Kesimpulan } \\
\text { Hipotesis (Hn) }\end{array}$} \\
\hline & & Langsung & $\begin{array}{c}\text { Tidak } \\
\text { Langsung } \\
\end{array}$ & Total & \\
\hline $\mathrm{H} 10$ & $\mathrm{X} 1 \longrightarrow \mathrm{Y} \longrightarrow \mathrm{Z}$ & 0,073 & 0,009729 & 0,082729 & Diterima \\
\hline $\mathrm{H} 11$ & $\mathrm{X} 2 \longrightarrow \mathrm{Y} \longrightarrow \mathrm{Z}$ & 0,045 & 0,020355 & 0,065355 & Diterima \\
\hline $\mathrm{H} 12$ & $\mathrm{X} 3 \longrightarrow \mathrm{Y} \longrightarrow \mathrm{Z}$ & 0,328 & 0,003312 & 0,331312 & Diterima \\
\hline $\mathrm{H} 13$ & $\mathrm{X} 4 \longrightarrow \mathrm{Y} \longrightarrow \mathrm{Z}$ & 0,268 & 0,006624 & 0,274624 & Diterima \\
\hline
\end{tabular}

Sumber: Data primer diolah (2019). 


\section{Koefisien Determinasi $\left(\mathbf{R}^{2}\right)$}

Hasil analisis regresi linear berganda menunjukkan nilai koefisien determinasi $\left(\mathrm{R}^{2}\right)$ pada model regresi I sebesar 0,296. Hasil tersebut dapat diartikan bahwa variabel ekspektasi kinerja, ekspektasi usaha, pengaruh sosial, dan kondisi yang mendukung mampu menjelaskan variasi niat perilaku menggunakan Itqan Mobile sebesar 29,6\%. Di sisi lain, koefisien determinasi pada model regresi II sebesar 0,346. Hasil tersebut diartikan bahwa variabel ekspektasi kinerja, ekspektasi usaha, pengaruh sosial, kondisi yang mendukung, dan niat perilaku menggunakan Itqan Mobile mampu menjelaskan variasi perilaku pengguna Itqan Mobile sebesar 34,6\%.

\section{Pembahasan}

\section{Pengaruh Ekspektasi Kinerja terhadap Niat Perilaku menggunakan Itqan Mobile}

Berdasarkan hasil analisis regresi yang telah dilakukan menunjukkan bahwa variabel ekspektasi kinerja (X1) tidak berperan menentukan niat perilaku menggunakan Itqan Mobile (Y). Hasil tersebut menunjukkan bahwa $\mathrm{H} 1$ ditolak dengan nilai signifikansi sebesar 0,081 atau lebih besar daripada 0,05 (Tabel 4). Hasil penelitian ini sejalan dengan penelitian terdahulu yang menunjukkan bahwa ekspektasi kinerja tidak berpengaruh pada konsumen untuk mengadopsi dan menggunakan mobile banking, sehingga konsumen perlu dilibatkan dalam program sensitisasi $m$-banking dengan frekuensi yang lebih banyak (Kwateng et al., 2018). Hal tersebut disebabkan beberapa anggota BMT Itqan merasa bahwa layanan Itqan Mobile belum terlalu mempengaruhi kinerja mereka. Meskipun Itqan Mobile dapat mempermudah pekerjaan anggotanya, seperti pembayaran token dan pulsa secara mobile, tetapi mayoritas anggota lebih cenderung memilih untuk datang ke counter atau tempat penjualan token dan pulsa, karena mereka merasa lebih nyaman melakukannya.

\section{Pengaruh Ekspektasi Usaha terhadap Niat Perilaku menggunakan Itqan Mobile}

Berdasarkan hasil analisis regresi yang telah dilakukan menunjukkan bahwa ekspektasi usaha (X2) berpengaruh positif dan signifikan terhadap niat perilaku menggunakan Itqan Mobile (Y). Hasil tersebut membuktikan bahwa $\mathrm{H} 2$ diterima dengan nilai signifikansi sebesar 0,000 atau lebih kecil daripada 0,05 (Tabel 4). Hasil penelitian ini sejalan dengan penelitian terdahulu yang menunjukkan bahwa ekspektasi usaha adalah faktor penentu kuat terhadap niat individu, khususnya pada wanita dibandingkan pria (Warsame \& Ireri, 2018). Ekspektasi usaha memiliki pengaruh yang signifikan terhadap niat perilaku untuk mengadopsi internet banking di kalangan orang dewasa (Warsame \& Ireri, 2018). Hasil penelitian ini menunjukkan bahwa para responden sepakat jika Itqan Mobile mudah untuk dipelajari cara penggunaannya. Layanan Itqan Mobile telah memiliki fitur-fitur yang cukup lengkap dan gampang menggunakannya (user friendly), sehingga usaha yang diperlukan untuk mempelajari penggunaan Itqan Mobile tidak terlalu banyak atau tidak menyulitkan penggunanya.

\section{Pengaruh sosial terhadap Niat Perilaku menggunakan Itqan Mobile}

Berdasarkan hasil analisis dalam penelitian ini menunjukkan bahwa pengaruh sosial tidak bereran dalam menentukan niat perilaku menggunakan Itqan Mobile. Hasil penelitian ini membuktikan bahwa $\mathrm{H} 3$ ditolak dengan nilai signifikansi sebesar 0,501 atau lebih besar daripada 0,05 (Tabel 4). Hasil penelitian ini sejalan dengan penelitian terdahulu yang menunjukkan bahwa pengaruh sosial tidak dapat menjelaskan perbedaan 
statistik pada niat perilaku untuk mengadopsi mobile banking yang berarti bahwa pelanggan tampaknya kurang tertarik pada rekomendasi dan sikap kelompok referensi mereka, seperti keluarga, teman, atau kolega mereka dalam merumuskan niat mereka untuk mengadopsi teknologi (Alalwana et. al. 2017). Hasil penelitian ini menunjukkan hasil sebaliknya. Temuan tersebut dapat terjadi disebabkan oleh teman-teman dekat mereka atau pun teman sesama anggota BMT Itqan tidak menggunakan Itqan Mobile, sehingga mayoritas dari mereka merasa belum perlu menggunakan layanan tersebut.

\section{Pengaruh Kondisi yang Mendukung terhadap Niat Perilaku menggunakan Itqan Mobile}

Berdasarkan hasil analisis yang telah dilakukan dalam penelitian ini menunjukkan bahwa kondisi yang mendukung tidak berperan menentukan niat perilaku menggunakan Itqan Mobile. Temuan penelitian ini menunjukkan bahwa $\mathrm{H} 4$ ditolak dengan nilai signifikansi sebesar 0,302 atau lebih besar daripada 0,05 (Tabel 4). Hasil ini sejalan dengan penelitian terdahulu yang menunjukkan bahwa inovasi menjadi faktor penting dalam menjelaskan adopsi pembayaran mobile (Oliveira et al., 2016). Pelanggan yang berpengetahuan luas lebih cenderung untuk mengadopsi pembayaran mobile, sehingga upaya untuk menunjukkan manfaat teknologi yang dikombinasikan dengan fitur keamanan melalui iklan atau cara lain secara memadai dapat menghasilkan nilai positif terhadap tindakan adopsi (Oliveira et al., 2016). Hasil penelitian ini menunjukkan hasil sebaliknya. Meskipun layanan Itqan Mobile mudah untuk diakses atau didownload, tetapi mayoritas anggota BMT Itqan belum mencoba untuk menggunakan aplikasi tersebut. Hal tersebut menyebabkan pengetahuan mereka tentang fitur-fitur Itqan Mobile pun belum ada, sehingga mereka tidak merasa mudah menggunakan layanan yang telah disediakan oleh BMT Itqan untuk mempermudah anggotanya.

\section{Niat Perilaku menggunakan Itqan Mobile berpengaruh terhadap Perilaku Peng- guna Itqan Mobile}

Berdasarkan hasil analisis yang telah dilakukan menunjukkan bahwa niat perilaku tidak berpengaruh terhadap perilaku pengguna Itqan Mobile. Hasil tersebut menunjukkan bahwa $\mathrm{H} 5$ ditolak dengan nilai signifikansi sebesar 0,236 atau lebih besar daripada 0,05 (Tabel 4). Temuan ini sejalan dengan penelitian terdahulu yang menyatakan bahwa penelitian perlu direplikasi apabila memungkinkan secara berurutan untuk mengkonfirmasi hasil penelitian tersebut, termasuk niat perilaku yang tidak memiliki pengaruh signifikan pada perilaku penggunaan, pada berbagai individu yang lebih luas di berbagai negara, lingkungan yang berbeda, budaya kelompok, dan teknologi (Baptista \& Oliveira, 2015). Hasil penelitian ini menunjukkan beberapa anggota merasa belum berniat untuk menggunakan layanan Itqan Mobile dikarenakan mereka merasa belum perlu menggunakannya. Mereka beralasan bahwa penggunaan aplikasi tersebut tidak diwajibkan oleh BMT Itqan, sehingga mereka tidak terlalu memikirkan untuk mengakses Itqan Mobile. Ada juga beberapa anggota yang merasa belum mengetahui tentang aplikasi ini. Namun, beberapa anggota yang lain telah menggunakannya karena dianjurkan oleh atasan mereka.

\section{Ekspektasi Kinerja berpengaruh terhadap Perilaku Pengguna Itqan Mobile}

Hasil analisis menunjukkan bahwa ekspektasi kinerja tidak berpengaruh terhadap perilaku pengguna Itqan Mobile. Hal tersebut didasarkan pada temuan H6 ditolak dengan nilai signifikansi sebesar 0,330 atau lebih besar daripada 0,05 (Tabel 4). Hasil ini sejalan dengan penelitian terdahulu yang menyatakan bahwa ekspektasi kinerja tidak 
memiliki hubungan dengan niat menggunakan mobile banking. Hasil itu dapat diartikan bahwa pelanggan tidak menemukan mobile banking sebagai alat atau teknologi yang berguna, fleksibel, dan mekanisme penghematan waktu (Islam et al., 2019). Hasil penelitian ini menunjukkan bahwa anggota yang telah menggunakan Itqan Mobile terutama pegawai BMT Itqan akan mempengaruhi pekerjaan mereka, karena layanan ini merupakan salah produk BMT Itqan. Namun, anggota yang belum memakai Itqan Mobile, penggunaan layanan ini tidak mempengaruhi kinerja mereka. Banyak dari mereka adalah pedagang yang sibuk berdagang setiap harinya dan bertempat tinggal di tempattempat terpencil, sehingga akses jaringan smartphone tidak terlalu bagus.

\section{Ekspektasi Usaha berpengaruh terhadap Perilaku Pengguna Itqan Mobile}

Temuan dalam penelitian ini menunjukkan bahwa ekspektasi usaha tidak berpengaruh terhadap perilaku pengguna menggunakan Itqan Mobile. Hasil tersebut menunjukkan bahwa $\mathrm{H} 7$ ditolak dengan nilai signifikansi sebesar 0,533atau lebih besar daripada 0,05 (Tabel 4). Hasil ini sejalan dengan penelitian terdahulu yang menunjukkan bahwa ekspektasi kinerja dan ekspektasi upaya ditemukan tidak memiliki efek langsung terhadap adopsi niat $m$-banking (Afshan \& Sharif, 2015). Hasil penelitian ini menunjukkan beberapa anggota BMT Itqan menyatakan bahwa mereka belum mencoba untuk menggunakan Itqan Mobile, sehingga mereka beranggapan sulit untuk menggunakan aplikasi Itqan Mobile. Mayoritas responden penelitian ini adalah lulusan SD, SMP dan SMA, sehingga pemahaman mereka kurang mengenai suatu mobile banking. Responden masih cenderung memilih untuk tidak menggunakan Itqan Mobile.

\section{Pengaruh Sosial berpengaruh terhadap Perilaku Pengguna Itqan Mobile}

Hasil analisis penelitian ini menunjukkan bahwa pengaruh sosial memiliki peran menentukan perilaku pengguna Itqan Mobile. Temuan ini membuktikan $\mathrm{H} 8$ dapat diterima dengan nilai signifikansi sebesar 0,000 atau lebih kecil daripada 0,05 (Tabel 4). Hasil tersebut sejalan dengan penelitian terdahulu yang menunjukkan efek pengaruh sosial perlu mendapat perhatian lebih lanjut (Zhou et al., 2010). Bank tradisional dapat memanfaatkan testimoni pengadopsi mobile banking sebelumnya agar pendapat dan ulasannya tersebut menghasilkan efek positif dari mulut ke mulut (words of mouth) pada perilaku adopsi berikutnya (Zhou et al., 2010). Hasil penelitian ini memprediksi jika teman-teman atau rekan sesama anggota BMT Itqan tidak menggunakan aplikasi Itqan Mobile, maka hal itu dapat mempengaruhi perilaku individu untuk memutuskan tidak memakai Itqan Mobile juga. Di sisi lain, pegawai BMT Itqan dianjurkan oleh Ketua BMT Itqan untuk menggunakan aplikasi Itqan Mobile agar mereka turut membantu memasarkan salah satu produk BMT Itqan.

\section{Kondisi yang Mendukung berpengaruh terhadap Perilaku Pengguna Itqan Mobile}

Temuan dalam analisis penelitian ini menunjukkan bahwa kondisi yang mendukung berpengaruh terhadap perilaku pengguna Itqan Mobile. Temuan tersebut menunjukkan bahwa H9 diterima dengan nilai signifikansi sebesar 0,002 atau lebih kecil daripada 0,05 (Tabel 4). Hasil tersebut sejalan dengan penelitian terdahulu yang menunjukkan bahwa responden membayar minat khusus pada keberadaan fasilitas, sumber daya, dan ketrampilan yang diperlukan untuk menggunakan mobile banking dengan sukses dan efektif (Alalwana et al., 2017). Hasil penelitian ini menunjukkan bahwa aplikasi Itqan Mobile mudah untuk diakses atau didownload. Namun, mayoritas respon- 
den belum mencoba untuk menggunakan aplikasinya, sehingga pengetahuan mereka mengenai fitur-fitur layanan Itqan Mobile juga terbatas.

\section{Ekspektasi Kinerja berpengaruh terhadap Perilaku Pengguna Itqan Mobile melalui Niat Perilaku sebagai Variabel Intervening}

Hasil analisis ini menunjukkan bahwa ekspektasi kinerja berpengaruh terhadap perilaku pengguna Itqan Mobile melalui niat perilaku sebagai variabel intervening. Hasil tersebut membuktikan bahwa H10 diterima dengan nilai pengaruh langsung sebesar 0,073 yang lebih besar dari nilai tidak langsung sebesar 0,009729 (Tabel 5). Temuan ini sejalan dengan penelitian terdahulu yang menunjukkan bahwa ekspektasi kinerja memiliki pengaruh signifikan terhadap niat perilaku mobile banking. Studi tersebut menegaskan bahwa ekspektasi kinerja adalah prediktor positif dan signifikan dari niat adopsi, ketika konsumen lebih cenderung menggunakan layanan $m$-banking apabila ekspektasi kinerjanya tinggi. Beberapa responden terutama bagi yang sudah menggunakan aplikasinya, seperti pegawai BMT Itqan, maka layanan tersebut sangat berguna untuk kehidupan pribadi mereka (Farah et al., 2018). Berdasarkan hasil penelitian ini, maka ekspektasi kinerja secara tidak langsung mempengaruhi perilaku pengguna Itqan Mobile mellaui niat perilaku menggunakannya sebagai variabel mediator.

\section{Ekspektasi Usaha berpengaruh terhadap Perilaku Pengguna Itqan Mobile melalui Niat Perilaku sebagai Variabel Intervening}

Berdasarkan hasil analisis yang telah dilakukan menunjukkan bahwa ekspektasi usaha berpengaruh terhadap perilaku pengguna Itqan Mobile melalui niat perilaku sebagai variabel intervening. Hasil tersebut membuktikan bahwa $\mathrm{H} 11$ diterima dengan nilai pengaruh langsung sebesar 0,045 yang lebih besar dari nilai tidak langsung sebesar 0,020355 (Tabel 5). Temuan ini sejalan dengan penelitian terdahulu yang menunjukkan bahwa niat perilaku memiliki pengaruh signifikan terhadap perilaku pengguna. Hasil tersebut juga menunjukkan bahwa pengguna di Amerika Serikat lebih cenderung menggunakan sistem apabila mereka memiliki niat untuk menggunakannya. Hal tersebut berbeda dengan pengguna dari Korea Selatan (Im, Seongtae, \& Myungsoo, 2011). Beberapa responden meyakini tidak perlu banyak usaha yang dilakukan untuk menggunakan aplikasi Itqan Mobile. Hal tersebut dikarenakan aplikasi Itqan Mobile dirancang agar mudah dipahami dan digunakan oleh para memakainya. Berdasarkan hasil penelitian ini, maka ekspektasi usaha secara tidak langsung berpengaruh terhadap perilaku pengguna Itqan Mobile yang dimediasi oleh niat perilaku menggunakannya.

\section{Pengaruh Sosial berpengaruh terhadap Perilaku Pengguna Itqan Mobile melalui Niat Perilaku sebagai Variabel Intervening}

Berdasarkan hasil analisis yang telah dilakukan menunjukkan bahwa Pengaruh Sosial berpengaruh terhadap Perilaku Pengguna Itqan Mobile melalui Niat Perilaku sebagai Variabel Intervening (H12 diterima) dengan nilai pengaruh langsung sebesar $0,328>$ nilai tidak langsung sebesar 0,003312 (Tabel 5). Hasil penelitian ini sejalan dengan penelitian terdahulu yang menunjukkan bahwa niat perilaku memiliki pengaruh signifikan terhadap perilaku pengguna. Hasil menunjukkan bahwa bank harus meningkatkan kepercayaan dan kepercayaan konsumen dalam menggunakan teknologi dengan memberikan layanan yang aman dan dapat diandalkan terutama ketika penggunaan sistem ini bersifat sukarela (Tarhini et al., 2015). Beberapa responden bahwa jika temanteman sesama anggota BMT Itqan tidak memakai Itqan Mobile maka setiap individu juga tidak memakai karena BMT Itqan juga tidak mewajibkan untuk memakai pada 
anggota BMT Itqan, kecuali pegawai BMT Itqan wajib untuk menggunakan selain untuk memasarkan produk. Namun, aplikasi tersebut juga digunakan pada saat penggajian karyawan BMT Itqan. Berdasarkan penelitian ini, maka pengaruh sosial secara tidak langsung mempengaruhi perilaku pengguna Itqan Mobile melalui niat perilaku menggunakannya sebagai variabel intervening.

\section{Kondisi yang Mendukung berpengaruh terhadap Perilaku Pengguna Itqan Mobile melalui Niat Perilaku sebagai Variabel Intervening}

Berdasarkan hasil analisis yang telah dilakukan menunjukkan bahwa Ekspektasi Usaha berpengaruh terhadap Perilaku Pengguna Itqan Mobile melalui Niat Perilaku sebagai Variabel Intervening (H13 diterima) dengan nilai pengaruh langsung sebesar $0,268>$ nilai tidak langsung sebesar 0,006624 (Tabel 5). Hasil penelitian ini sejalan dengan penelitian terdahulu yang menunjukkan bahwa kondisi yang mendukung memiliki pengaruh signifikan terhadap niat perilaku. Hasil menunjukkan bahwa responden membayar bunga tertentu dalam keberadaan fasilitas, sumber daya, keterampilan, dan bantuan yang diperlukan untuk menggunakan layanan pembayaran bank dengan sukses (Gupta et al., 2019). Beberapa responden bahwa pentingnya fasilitas yang diberikan agar mudah dimengerti oleh para pemakainya. Menurut pernyataan Ketua BMT Itqan bahwa fasilitas atau pun fitur-fitur Itqan Mobile sudah didisain untuk mempermudah para pemakainya dan fitur-fiturnya disesuaikan dengan produk-produk BMT Itqan, seperti pinjaman, pembelian, dan simpanan. Berdasarkan penelitian ini, maka kondisi yang mendukung secara tidak langsung berpengaruh terhadap perilaku pengguna Itqan Mobile yang dimediasikan oleh niat perilaku menggunakan aplikasi tersebut.

\section{KESIMPULAN DAN SARAN}

\section{Kesimpulan}

Berdasarkan hasil penelitian ini, variabel ekspektasi usaha secara parsial memiliki peran menentukan niat perilaku menggunakan Itqan Mobile, sedangkan variabel ekspektasi kinerja, pengaruh sosial, dan kondisi yang mendukung tidak memiliki peran secara parsial dalam menentukan niat perilaku menggunakan Itqan Mobile. Ekspektasi kinerja, ekspektasi usaha, dan niat perilaku menggunakan Itqan Mobile secara parsial tidak memiliki peran menentukan perilaku pengguna Itqan Mobile, sedangkan pengaruh sosial dan kondisi yang mendukung secara parsial berperan menentukan perilaku pengguna Itqan Mobile. Selanjutnya, ekspektasi kinerja, ekspektasi usaha, pengaruh sosial, dan kondisi yang mendukung secara parsial berperan secara tidak langsung menentukan perilaku pengguna Itqan Mobile melalui niat perilaku menggunakan Itqan Mobile sebagai variabel mediasi (intervening).

\section{Saran}

Berdasarkan hasil penelitian ini, indikator ekspektasi kinerja memiliki nilai gap tertinggi, yaitu kesesuaian pekerjaan, sehingga BMT Itqan disarankan untuk menambahkan fitur-fitur yang dapat dipakai secara umum oleh seluruh anggotanya. Indikator ekspektasi usaha dengan nilai gap tertinggi adalah kompleksitas, maka BMT Itqan disarankan untuk melakukan kegiatan-kegiatan kecil, seperti diskusi bersama para anggota BMT Itqan dan memberikan edukasi mendalam mengenai Itqan Mobile agar anggota lebih memahami bahwa Itqan Mobile mudah digunakan. 
Indikator pengaruh sosial dengan nilai gap tertinggi adalah norma subyektif, sehingga BMT Itqan disarankan untuk mewajibkan seluruh anggotanya menggunakan Itqan Mobile. Khususnya, perkumpulan-perkumpulan atau majelis yang juga harus tertarik untuk merekomendasikan Itqan Mobile. Indikator kondisi yang mendukung memiliki nilai gap tertinggi, yaitu kondisi fasilitas, sehingga BMT Itqan disarankan untuk tidak memungut biaya tambahan apa pun, apabila mereka ingin mengakses Itqan Mobile. Indikator niat perilaku menggunakan Itqan Mobile dengan nilai gap tertinggi adalah keinginan untuk selalu mencoba menggunakan, maka BMT Itqan disarankan untuk mendorong anggotanya lebih aktif dan ikut berpartisipasi menggunakan Itqan Mobile.

\section{DAFTAR REFERENSI}

Aaron, M., Rivadeneyra, F., \& Sohal, S. (2017). Fintech: Is This Time Different? A Framework for Assessing Risks and Opportunities for Central Banks. Bank of Canada Staff Discussion Paper, 10(July). Canada: Bank of Canada.

Abbasi, M. S., Chandio, F. H., Soomro, A. F., \& Shah, F. (2011). Social Influence, Voluntariness, Experience and the Internet Acceptance: An Extension of Technology Acceptance Model within a South-Asian Country Context. Journal of Enterprise Information Management, 24(1), 30-52. https://doi.org/10.1108/1741039111109 7410.

Afshan, S., \& Sharif, A. (2015). Acceptance of Mobile Banking Framework in Pakistan. Telematics and Informatic, 33(2), 43-48.

Ajzen, I. (1991). The Theory of Planned Behavior. Organizational Behavior and Human Decision Processes, 50(2), 179-211. https://doi.org/10.1016/07495978(91)900 20-T.

Akbar, C. (2013). Posisi Hukum BMT Dinilai Sudah Semakin Jelas. Hidayatullah, 17 April. Diakses dari https://www.hidayatullah.com/berita/read/2013/01/08/65279/ posisi-hukum-bmt-dinilai-sudah-semakin-jelas.html.

Alalwana, A. A., Dwivedib, Y. K., \& Ranab, N. P. (2017). Factors Influencing Adoption of Mobile Banking by Jordanian Bank Customers: Extending UTAUT2 with Trust. International Journal of Information Management, 37(3), 99-110.

Altawallbeh, M., Thiam, W., Alshourah, S., \& Fong, S. F. (2015). Do the Instructors Differ in Their Behavioral Intention to Adopt E-Learning Based on Age, Gender, and Internet Experience? Journal of Education and Practice, 6(18), 41-50.

Arikunto, S. (2016). Prosedur Penelitian: Suatu Pendekatan Praktik. Jakarta: Rineka Cipta.

Auliani, P. A. (2018). Geliat Fintech di Era Industri 4.0. Kompas, 24 Oktober. Diakses dari https://ekonomi.kompas.com/read/2018/10/18/144300126/geliat-fintech-diera-industri-40? page $=$ all.

Baptista, G., \& Oliveira, T. (2015). Understanding Mobile Banking: The Unified Theory of Acceptance and Use of Technology Combined with Cultural Moderators. Computers in Human Behavior, 50(1), 418-430.

BMT Itqan (2018). Laporan RAT Tahun Buku 2019. Diakses 24 Oktober 2019 dari http://bmtitqan.org/pencapaian /detail/7/laporan-rat-tahun-buku-2019.html. 
Davis, F. D., Bagozzi, R. P., \& Warshaw, P. R. (1992). Extrinsic and Intrinsic Motivation to Use Computers in the Workplace. Journal of Applied Social Psychology, 22(14), 1111-1132. https://doi.org/10.1111/j.1559-1816.1992.tb009 45.x.

DeGennaro, A. J. (2010). Application of Multiple Intelligence Theory to an Elearning Technology Acceptance Model. ProQuest Dissertations and Theses, 252.

Douglas W, A., Barberis, J., \& Buckley, R. P. (2015). The Evolution of FinTech: A New Post-Crisis Paradigm? University of Hong Kong Faculty of Law Research Paper No. 2015/047.

Farah, M. F., Hasni, M. J. S., \& Abbas, A. K. (2018). Mobile Banking Adoption: Empirical Evidence from the Banking Sector in Pakistan. International Journal of Bank Marketing, 36(7), 12-20. https://doi.org/10.1108/IJBM-10-2017-0215.

Ghozali, I. (2016). Aplikasi Analisis Multivariate dengan Program IBM SPSS 23 (edisi ke-8). Semarang: Badan Penerbit Universitas Diponegoro.

Gupta, K. P., Manrai, R., \& Goel, U. (2019). Factors Influencing Adoption of Payments Banks by Indian Customers: Extending UTAUT with Perceived Credibility. Journal of Asia Business Studies, 13(2), 173-195. https://doi.org/10.1108/JABS07-2017-0111.

Hamrul, H., Soedijono, B., \& Amborowati, A. (2013). Mengukur Kesuksesan Penerapan Sistem Informasi Akademik (Studi Kasus Penerapan Sistem Informasi STMIK Dipanegara Makassar). Seminar Nasional Informatika 2013 (SemnasIF), $140-146$.

Hanel, A. (1989). Organisasi Koperasi: Pokok-pokok Pikiran Mengenai Organisasi Koperasi dan Kebijakan Pengembangannya di Negara-negara Berkembang. Bandung: Universitas Padjadjaran (Ed.).

Hartoyo, A. (2019). Menyongsong Perkembangan BMT di Indonesia. Solopos, 24 Oktober. Diakses dari https://sharianews.com/posts/menyongsong-perkembanganbmt-di-indonesia.

Hasan, E. F. (2017). Indonesia dan Halal LifeStyle. Islampos, 17 April. Diakses dari https://www.islampos.com/indonesia-dan-halal-lifestyle-2982.

Huda, N., \& Heykal, M. (2010). Lembaga Keuangan Islam. Jakarta: Kencana.

Im, I., Seongtae, H., \& Myungsoo, K. (2011). An International Comparison of Technology Adoption: Testing the UTAUT Model. Journal Information and Management, 48(1), 1-8. https://doi.org/10.1016/j.im.2010.09.001.

Islam, M. S., Karia, N., Khaleel, M., Fauzi, F. B. A., Soliman, M., Khalid, J., Mamun, A. Al. (2019). Intention to Adopt Mobile Banking in Bangladesh: An Empirical Study of Emerging Economy. International Journal of Business Information Systems, 31(1), 1-16.

Kautonen, T., Luoto, S., \& Tornikoski, E. T. (2010). Influence of Work History on Entrepreneurial Intentions in "Prime Age" and "Third Age": A Preliminary Study. International Small Business Journal, 28(6), 583-601. https://doi.org/10.1177/0266242610368592.

Kwateng, K. O., Atiemo, K. A. O., \& Appiah, C. (2018). Acceptance and Use of Mobile Banking: An Application of UTAUT2. Journal of Enterprise Information Management, 32(1), 118-151. https://doi.org/10.1108/JEIM-03-2018-0055. 
Laukkanen, T., \& Pasanen, M. (2008). Mobile Banking Innovators and Early Adopters: How They Differ from Other Online Users? Journal of Financial Services Marketing, 13(2), 86-94. https://doi.org/10.1057/palgrave.fsm.4760077.

Mamman, M., Ogunbado, A. F., \& Abu-Bakr, A. S. (2016). Factors Influencing Customer's Behavioral Intention to Adopt Islamic Banking in Northern Nigeria: A Proposed Framework. IOSR Journal of Economics and Finance, 7(1), 51-55. https://doi.org/10.9790/5933-07135155.

Martins, C., Oliveira, T., \& Popovic, A. (2014). Understanding the Internet Banking Adoption: A Unified Theory of Acceptance and Use of Technology and Perceived Risk Application. International Journal of Information Management, 34(1), 1-34.

Oliveira, T., Thomas, M., \& Baptista, G. (2016). Mobile Payment: Understanding the Determinants of Customer Adoption and Intention to Recommend the Technology. Computers in Human Behavior, 61(1), 404-414. https://doi.org/10.1016/j.chb. 2016.03.030.

Otoritas Jasa Keuangan (2019). Statistik Perbankan Syariah. Diakses pada 5 November 2019 di https://ojk.go.id/id/kanal/syariah/data-dan-statistik/statistik-perbankansyariah/Default.aspx.

Pituch, K. A., \& Lee, Y.K. (2006). The Influence of System Characteristics on Elearning Use. Computers and Education, 47(2), 222-244. https://doi.org/10.1016/j.com pedu.2004.10.007.

Purnomo, H. (2018). Indonesia Kini Punya Payung Hukum Aturan Fintech. CNBC Indonesia, 17 April. Diakses dari https://www.cnbcindonesia.com/tech/20180901144740-37-31329/indonesia-kinipunya-payung-hukum-aturan-fintech.

Rahman, A. (2015). Toward a Comprehensive Conceptualization of Digital Divide and Its Impact on E-government System Success. Advances in Business Marketing and Purchasing, 23(1), 291-488. https://doi.org/10.1108/S1069096420150000023003.

Ridwan, M. (2004). Manajemen Baitul Maal Wat Tamwil (BMT). Yogyakarta: UII Press.

Sakti, A. (2013). Pemetaan Kondisi dan Potensi BMT: Kemitraan dalam Rangka Memperluas Pasar dan Jangkauan Pelayanan Bank Syariah kepada Usaha Mikro. Al-Muzara'ah, 1(1), 1-18. https://doi.org/10.29244/jam.1.1.1-18.

Salama, S. C. U. (2018). Babak Baru BMT di Indonesia. Medcom, 24 Oktober. Diakses dari https://www.medcom.id/ekonomi/analisa-ekonomi/5b2VgYvb-babak-barubmt-di-indonesia.

Schleife, K. (2010). What Really Matters: Regional versus Individual Determinants of the Digital Divide in Germany. Research Policy, 39(1), 173-185. https://doi.org/10. 1016/j.respol.2009.11.003.

Sekaran, U. \& Bougie, R. (2017). Metode Penelitian untuk Bisnis Pendekatan Pengembangan Keahlian. Jakarta: Salemba Empat.

Shidiq, S. (2016). Ushul Fiqh. Jakarta: PT Intimedia Cipta Nusantara.

Sipior, J. C., Ward, B. T., \& Connolly, R. (2011). The Digital Divide and T-government in the United States: Using the Technology Acceptance Model to Understand Usage. European Journal of Information Systems, 20(3), 308-328. https://doi.org/10. 1057/ejis.2010.64. 
Soemitra, A. (2010). Bank dan Lembaga Keuangan Syariah. Jakarta: Kencana.

Sugiyono, S. (2017). Metode Penelitian Kuantitatif, Kualitatif, dan R\&D. Bandung: CV Alfabeta.

Suharsih, S. (2019). OJK Sebut Pasar Fintech Syariah Masih Besar, Ini Alasannya. Solopos, 24 Oktober. Diakses dari https://www.solopos.com/ojk-sebut-pasarfintech-syariah-masih-besar-ini-alasannya-1012604.

Tarhini, A., El-Masri, M., Ali, M., \& Serrano, A. (2015). Extending the UTAUT Model to Understand the Customers' Acceptance and Use of Internet Banking in Lebanon: A Structural Equation Modeling Approach. Journal of Information Technology \& People. 29(4), 1-20. https://doi.org/10.1108/ITP-02-2014-0034.

Taylor, S., \& Todd, P. A. (1995). Extending the UTAUT Model to Understand the Customers' Acceptance and Use of Internet Banking in Lebanon: A Structural Equation Modeling Approach. Information Systems Research, 29(4), 144-176. https://doi.org/10.1287/isre.6.2.144.

Uly, Y. A. (2018). Indonesia Harus Manfaatkan Digitalisasi Dorong Ekonomi dan Keuangan Syariah. Okezone, 24 Oktober. Diakses dari https://economy.okezone. com/read/2018/12/12/20/1990262/indonesia-harus-manfaatkan-digitalisasidorong-ekonomi-dan-keuangan-syariah.

Vallerand, R. J., Deshaies, P., Cuerrier, J. P., Pelletier, L. G., \& Mongeau, C. (1992). Ajzen and Fishbein's Theory of Reasoned Action as Applied to Moral Behavior: A Confirmatory Analysis. Journal of Personality and Social Psychology, 62(1), 98-109. https://doi.org/10.1037/0022-3514.62.1.98.

Venkatesh, V. (2000). Determinants of Perceived Ease of Use: Integrating Control, Intrinsic Motivation, Acceptance Model. Institute for Operations Research and the Management Sciences, 11(4), 342-365.

Venkatesh, V., Davis, F. D., Morris, M. G., \& Davis, G. B. (2003). User Acceptance of Information Technology: Toward a Unified View. MIS Quarterly, 27(3), 425.

Venkatesh, V., Thong, J.Y.L. \& Xu, X. (2012). Consumer Acceptance and Use of Information Technology: Extending The Unified Theory of Acceptance and Use of Technology. MIS Quarterly, 36(1), 157-178.

Warsame, M. H., \& Ireri, E. M. (2018). Moderation Effect on Mobile Microfinance Services in Kenya: An Extended UTAUT Model. Journal of Behavioral and Experimental Finance, 18(1), 67-75. https://doi.org/10.1016/j.jbef.2018.01.008.

Zhou, T., Lu, Y., \& Wang, B. (2010). Integrating TTF and UTAUT to Explain Mobile Banking User Adoption. Computers in Human Behavior, 26(4), 760-767. https://doi.org/10.1016/j.chb.2010.01.013. 